Research Article

\title{
Effect of the Noble Metals Addition on the Oxidation Behavior of $\mathrm{Ni}_{3} \mathrm{Al}$
}

\author{
J. J. Ramos-Hernandez $\mathbb{D},{ }^{1}$ J. Porcayo-Calderon $\mathbb{D D}^{2}{ }^{2}$ J. G. Gonzalez-Rodriguez, ${ }^{2}$ Jan Mayén, $^{3}$ \\ G. Lara-Rodriguez, ${ }^{4}$ V. M. Salinas-Bravo $\mathbb{i D},{ }^{5}$ and L. Martinez-Gomez $\mathbb{D}{ }^{6,7}$ \\ ${ }^{1}$ Facultad de Química, Universidad Nacional Autónoma de Mexico, Edificio B, Cd. Universitaria, 04510 Ciudad de \\ Mexico, Mexico \\ ${ }^{2}$ CIICAp, Universidad Autónoma del Estado de Morelos, Avenida Universidad 1001, 62209 Cuernavaca, MOR, Mexico \\ ${ }^{3}$ CIATEQ A.C., Eje 126 No. 225, Zona Industrial, 78395 San Luis Potosí, SLP, Mexico \\ ${ }^{4}$ Instituto de Investigaciones en Materiales, Universidad Nacional Autónoma de Mexico, Cd. Universitaria, 04510 Ciudad de \\ Mexico, Mexico \\ ${ }^{5}$ Instituto Nacional de Electricidad y Energías Limpias, Avenida Reforma 113, Colonia Palmira, 62490 Cuernavaca, MOR, Mexico \\ ${ }^{6}$ Instituto de Ciencias Físicas, Universidad Nacional Autónoma de Mexico, Avenida Universidad s/n, 62210 Cuernavaca, \\ MOR, Mexico \\ ${ }^{7}$ Corrosion y Protección (CyP), Buffon 46, 11590 Mexico City, Mexico
}

Correspondence should be addressed to J. Porcayo-Calderon; jporcayoc@gmail.com

Received 6 July 2017; Revised 12 October 2017; Accepted 1 November 2017; Published 17 January 2018

Academic Editor: Amit Bandyopadhyay

Copyright () 2018 J. J. Ramos-Hernandez et al. This is an open access article distributed under the Creative Commons Attribution License, which permits unrestricted use, distribution, and reproduction in any medium, provided the original work is properly cited.

\begin{abstract}
This paper discusses the effect of the addition of noble metals on the microstructure, mechanism, and oxidation kinetics of the $\mathrm{Ni}_{3} \mathrm{Al}$ intermetallic alloy. $\mathrm{Ni}_{3} \mathrm{Al}$ was doped with $1 \%$ (atomic percent) of $\mathrm{Au}, \mathrm{Ag}, \mathrm{Pd}$, and Pt. Oxidation behavior of the alloys was evaluated at 900,1000 , and $1100^{\circ} \mathrm{C}$ in $\mathrm{O}_{2}$ for 24 hours. XRD analysis showed that the addition of noble metals favored the oxide growth on preferential crystallographic planes. In addition, the preferential substitution of the noble metals in the $\mathrm{Ni}_{3} \mathrm{Al}$ structure modifies the surface composition by increasing the $\mathrm{Al} / \mathrm{Ni}$ ratio. It was observed that most of the alloys showed a subparabolic behavior, and only the intermetallic base and the alloy doped with $\mathrm{Ag}$ show a parabolic behavior at $900^{\circ} \mathrm{C}$. The developed oxides were analyzed both superficially and in cross section by scanning electron microscopy (SEM) and energy dispersive X-ray analysis (EDXA). It was evident that only the intermetallic base showed the formation of a duplex oxide scale $\left(\mathrm{Al}_{2} \mathrm{O}_{3} / \mathrm{NiO}\right)$. The alloys doped with noble metals showed the oxide growth practically of pure $\mathrm{Al}_{2} \mathrm{O}_{3}$. This was due to a decrease in the diffusion of the $\mathrm{Ni}$ cations because of the presence of the noble metals in the crystalline structure.
\end{abstract}

\section{Introduction}

$\mathrm{Ni}_{3} \mathrm{Al}$ intermetallic compounds are excellent candidates for high-temperature structural applications due to their thermochemical and mechanical properties. They can perform beyond conventional temperatures because of their excellent resistance to corrosion and oxidation [1]. During solidification of an alloy with stoichiometry close to that of $\mathrm{Ni}_{3} \mathrm{Al}$, there is in the liquid phase a competition for phase stability between $\beta_{\mathrm{NiAl}}, \gamma_{\mathrm{Ni3Al}}^{\prime}$, and $\gamma_{\mathrm{Ni}}$ with stable eutectic $\left(\beta-\gamma^{\prime}\right)$, metastable $(\beta-\gamma)$, and peritectic $\left(\gamma^{\prime}-\gamma\right)$ phases which have common borders in the $\mathrm{Ni}$ - $\mathrm{Al}$ binary diagram. Because the region of phase stability $\gamma^{\prime}$ is very narrow, any deviation in the $\mathrm{Ni} / \mathrm{Al}$ ratio favors the stability of any of the aforementioned phases; that is, an increase in the $\mathrm{Ni}$ content tends to favor the stability of $\gamma^{\prime}-\gamma$ phase. According to Verin [2], the microstructure of the Ni-23Al-0.001Ce-0.004Co (at \%) is composed of a combination of dendritic phases $\gamma^{\prime}$ and $\gamma$, where the matrix is the phase $\gamma^{\prime}$ and the interdendritic phase is the phase $\gamma$; similar results were obtained by Chiba and Hanada [3] for the alloy Ni-23Al (at \%) and Jozwik et al. [4] for the alloy Ni-22Al-0.002Zr-0.001B (at \%). Moreover, Hunziker 
and Kurz [5] mentioned that the directional solidification of intermetallic $\mathrm{Ni}-25 \mathrm{Al}$ (at \%) shows a microstructure where the phases $\beta, \gamma$, and $\gamma^{\prime}$ are found. In this case, the $\gamma^{\prime}$ phase is formed during cooling of metastable eutectic $\beta-\gamma$. It has been shown that there are subsequent transformations after the solidification process, which complicates the interpretation of the phases produced.

On the other hand, the solidification rate is a factor that influences the microstructure of the alloy. When the solidification is slow, the convection in the liquid phase favors formation of a single $\gamma^{\prime}$-phase. However, in a rapid solidification process, there is little convection in the liquid phase and it promotes the formation of a structure with phases $\gamma^{\prime \prime}$ and $\beta$ [6]. The addition of a third element to the $\mathrm{Ni}-\mathrm{Al}$ system may stabilize or destabilize a given phase. According to Inoue et al. [7], the addition of Cr, Mn, Fe, Co, or Si destabilizes the phase $\gamma^{\prime}$, and according to Goetzinger et al. [8], the addition of Ti stabilizes the phase. Sun et al. [9] indicate that Pd, Ag, and $\mathrm{Cu}$ are elements forming the $\gamma$ phase, while Pint et al. [10] show that Pt promotes the reduction of the temperature of the phase transformation from $\beta$ to $\gamma^{\prime}$ during the process of cooling and phase transformation from $\gamma^{\prime}$ to $\beta$ during heating.

During the oxidation process, $\beta$ and $\gamma^{\prime}$ phases play an important role due to their content of $\mathrm{Al}$ [11]. According to Haerig and Hofmann [12], in the early stages of the oxidation process, $\mathrm{NiO}$ and $\mathrm{Al}_{2} \mathrm{O}_{3}$ are formed simultaneously due to the diffusion of cations towards the outside of the alloy. Bardi et al. [13] show that the growth of the oxide is in the form of islands. $\mathrm{Al}$ consumption owing to the formation of $\mathrm{Al}_{2} \mathrm{O}_{3}$ diminishes the aluminum content below $17 \%$ (at \%), which is the content needed to form the outer protective layer [14]. This favors the growth of $\mathrm{NiO}$ onto the $\mathrm{Al}_{2} \mathrm{O}_{3}$ layer. This pattern occurs because of the conducting properties of the formed oxides: $\mathrm{Al}_{2} \mathrm{O}_{3}$ is an amphoteric oxide (movement of cations and anions is possible) allowing outward diffusion of $\mathrm{Ni}^{+}$cations. $\mathrm{Al}_{2} \mathrm{O}_{3}$ forms internally due to inward diffusion of $\mathrm{O}^{2-}$ anions, while $\mathrm{NiO}$ is a p-type conductor, which preferably promotes conduction of cations [15-17]. $\mathrm{Al}_{2} \mathrm{O}_{3}$ growth onto alloys such as $\mathrm{Ni}_{3} \mathrm{Al}$ can adopt different crystallographic arrangements: between 427 and $927^{\circ} \mathrm{C}$, the $\gamma-\mathrm{Al}_{2} \mathrm{O}_{3}$ phase is stable; until $1077^{\circ} \mathrm{C}$, the $\theta-\mathrm{Al}_{2} \mathrm{O}_{3}$ phase is stable; and above $1077^{\circ} \mathrm{C}$, the $\alpha-\mathrm{Al}_{2} \mathrm{O}_{3}$ phase is stable [18]. The $\theta \rightarrow \alpha$ transformation is accompanied by a change in the transport properties of the scale. The $\theta-\mathrm{Al}_{2} \mathrm{O}_{3}$ scale mainly grows by outward diffusion of cations, forming cavities in the scale/alloy interface, resulting in the deterioration of the adhesion layer on the substrate. In contrast, the growth of $\alpha$ scale is dependent on the diffusion of the $\mathrm{O}^{2-}$ anion inwards, so that the oxide fills the preformed cavities. This improves the adhesion of the layer on the substrate. Therefore, it is desirable for the growth of an $\alpha-\mathrm{Al}_{2} \mathrm{O}_{3}$ layer $[1,14]$. It has been observed that the only growth of an outer scale of $\mathrm{Al}_{2} \mathrm{O}_{3}$ is possible under the following conditions, by increasing both the temperature and concentration of $\mathrm{Al}[12]$, where the oxidation process is carried out at oxygen partial pressures below the equilibrium of $\mathrm{NiO}$ formation $[13,19-21]$ and also in alloys which were implanted with $\mathrm{B}^{+}$and $\mathrm{Cr}^{+}$ions [14]. Increasing the oxygen partial pressure and temperature, it is possible to form the spinel $\mathrm{NiAl}_{2} \mathrm{O}_{4}$ at the $\mathrm{NiO} / \mathrm{Al}_{2} \mathrm{O}_{3}$ interface [22].
Garza et al. [23] attributed this behavior to the difference between the free energies of formation of $\mathrm{Al}_{2} \mathrm{O}_{3}$ and $\mathrm{NiO}$ which is four times larger than that between $\mathrm{Al}_{2} \mathrm{O}_{3}$ and $\mathrm{NiAl}_{2} \mathrm{O}_{4}$. Velon and Olefjord [15] mentioned that the spinel could also be formed in the initial stages of oxidation at low temperatures $\left(300^{\circ} \mathrm{C}\right)$.

A key aspect to increase the oxidation resistance of an alloy is to improve the adherence of the protective oxide mainly because most applications implicate high-temperature thermal cycles $[13,24]$. The most effective method is the addition of elements or compounds such as $\mathrm{Hf}, \mathrm{Y}, \mathrm{Zr}, \mathrm{Cr}, \mathrm{Pd}$, $\mathrm{Pt}$, and $\mathrm{SiC}$ [25-31], which can change the localized concentration of aluminum and reduce its growth rate. Gleeson et al. [32] indicate that the addition of Pt has beneficial effects in promoting the formation of a stable $\mathrm{Al}_{2} \mathrm{O}_{3}$ scale. $\mathrm{Pt}$ is an unreactive element whose addition decreases the chemical activity of $\mathrm{Al}$ in the $\gamma^{\prime}$ phase, and it increases the $\mathrm{Al} / \mathrm{Ni}$ ratio, which promotes the formation of $\mathrm{Al}_{2} \mathrm{O}_{3}$ in certain crystallographic planes and increases the $\mathrm{Al}$ diffusion into the formed scale. It has been calculated that the preferential site of substitution of noble metals like $\mathrm{Ag}, \mathrm{Au}, \mathrm{Pd}$, and $\mathrm{Pt}$ in the $\mathrm{Ni}_{3} \mathrm{Al}$ structure occurs in locations where there are normally nickel atoms [33-37]; therefore, the addition of these elements can modify the oxidation behavior of the alloy. Therefore, this paper evaluates the effect of the addition of these elements in low concentration (1 at.\%) on the oxidation behavior of the $\mathrm{Ni}_{3} \mathrm{Al}$ intermetallic alloy.

\section{Experimental Procedure}

The intermetallic alloys with nominal composition $\mathrm{Ni}_{75} \mathrm{Al}_{25}$ and $\mathrm{Ni}_{75} \mathrm{Al}_{24} \mathrm{M}_{1}$ (where $\mathrm{M}=\mathrm{Ag}, \mathrm{Au}, \mathrm{Pd}$, and $\mathrm{Pt}$ ) were manufactured in quartz crucibles in an induction furnace under inert atmosphere using elements with purity higher than $99.99 \%$. The ingots were prepared by the fusion of stoichiometric amounts of the high-purity elements (solid rods), and the melt was homogenized by the convective currents generated by the induction furnace. After melting the metal elements, the ingots were allowed to cool to room temperature inside the induction furnace. From the ingots, samples were cut with dimensions of $20 \times 5 \times 2 \mathrm{~mm}$ to carry out the tests.

XRD analysis of alloys was carried with a Bruker D8 Advance diffractometer equipped with a $\mathrm{Cu} \mathrm{K} \alpha(k=1.5418 \AA$; $40 \mathrm{kV})$ monochromatic source and a LYNXEYE ${ }^{\mathrm{TM}} 1 \mathrm{D}$ positional detector. Scans were performed from $2 \theta=5^{\circ}$ to $100^{\circ}$ with a $0.02^{\circ}$ step and an irradiation time of 0.2 seconds.

In order to reveal the microstructure of the intermetallic alloys, they were etched by immersing in $\mathrm{HF}-\mathrm{HNO}_{3}$ solution (1: 1 molar ratio) for 5 to 10 seconds at room temperature.

For the oxidation test, samples were grinded with a silicon carbide paper to 600-grit size, washed with water, and ultrasonically cleaned with acetone. In order to have a larger reaction area, two samples were employed in each test: one was used for surface analysis and the other for crosssectional analysis.

Oxidation tests were carried out in pure oxygen at 900, 1000 , and $1100^{\circ} \mathrm{C}$. This range was chosen since at these temperatures, there is a change in the stability of the different 


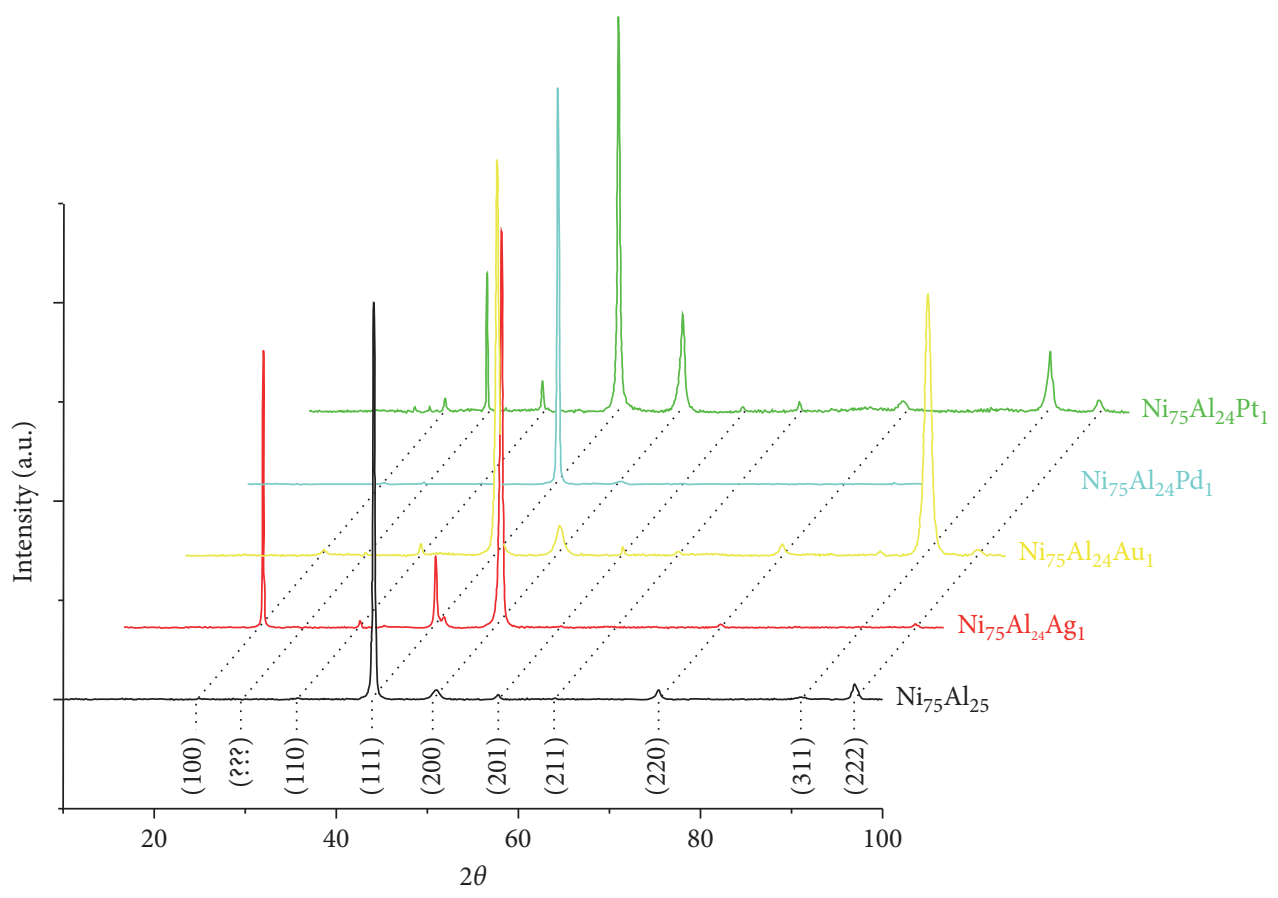

FIgURE 1: The XRD patterns of $\mathrm{Ni}_{3} \mathrm{Al}$ and $\mathrm{Ni}_{3} \mathrm{Al}$ doped with 1 at.\% of noble metals.

phases of $\mathrm{Al}_{2} \mathrm{O}_{3}$; at $900^{\circ} \mathrm{C}$, transition between $\gamma$-phase and $\theta$-phase begins; at $1000^{\circ} \mathrm{C}, \theta$-phase is stable; and at $1100^{\circ} \mathrm{C}$, $\alpha$-phase is stable. Before each test, the electric furnace was preheated to the experimental temperature. The record of the weight gain curves as a function of exposure time was done with a thermobalance CI MK2-M5 Head LM 2-01 and the LabWeigh software. Analyses were carried out by means of a scanning electron microscope (Zeiss model DSM 960) and the energy dispersive $\mathrm{X}$-ray analysis (EDXA).

\section{Results and Discussion}

3.1. XRD Analysis of Alloys. The XRD profiles of the alloys with and without noble metal additions are shown in Figure 1. The XRD profile of the $\mathrm{Ni}_{3} \mathrm{Al}$ alloy shows the characteristic peaks (111), (200), (220), (311), and (222) corresponding to the $L_{12}$ superstructure ( $\gamma^{\prime}$-phase), and their relative intensities are consistent with previous reports [38-40], which indicate a complete transformation from metals to the $\mathrm{Ni}_{3} \mathrm{Al}$ intermetallic alloy.

The peaks observed in the XRD profiles of the doped alloys are wide, suggesting a small crystallite size. In addition, the intensities of some peaks increase and decrease depending on the added noble metal. The $\mathrm{Ni}_{75} \mathrm{Al}_{24} \mathrm{Ag}_{1}$ profile shows highest intensities in (100) and (200), and the intensity of the peak decreased in (111); this suggests the crystal growth in two preferential planes. This preferential growth was also observed in the $\mathrm{Ni}_{75} \mathrm{Al}_{24} \mathrm{Pd}_{1}$ alloy, where the profile shows a slight increase in the (222) peak, indicating a preferential unidirectional growth [41]. The XRD profile for the $\mathrm{Ni}_{75} \mathrm{Al}_{24} \mathrm{Au}_{1}$ alloy shows a notable increase in the intensity of the (311) peak and a slight increase in the intensity of the (200) peak, and the characteristic peak (111) shows no change. On the other hand, the XRD profile of the
$\mathrm{Ni}_{75} \mathrm{Al}_{24} \mathrm{Pt}_{1}$ alloy shows an increase in the intensity of all its peaks, and an unidentified peak at $2 \theta=29.56$ is observed. Considering that the positions of the atoms in the unit cell affect the intensities but not the directions of the diffracted beams [42], the change in peak intensities can be completely attributable to the addition of noble metals.

Properties such as hardness show a significant dependence on crystallographic planes: for $\mathrm{Ni}_{3} \mathrm{Al}$, the highest value occurs in (100), followed by (111) and (110) [43]. However, several studies about the $\mathrm{Ni}_{3} \mathrm{Al}$ oxidation indicate that there are no significant differences in the oxidation behavior between planes (100), (110), and (111) [44-48]. Taking into account that the planes (100) and (110) consist of a series of two layers: the most stable having a composition of $50 \% \mathrm{Ni}$ and $50 \% \mathrm{Al}$ and the other with $100 \% \mathrm{Ni}$ and the plane (111) having a composition of $75 \% \mathrm{Ni}-25 \% \mathrm{Al}[49,50]$; then due to it, it is possible the presence of zones with different chemical compositions onto alloy surface (i.e., change in the $\mathrm{Al} / \mathrm{Ni}$ ratio). In addition, substitution at preferential sites by the addition of noble metals can further change the surface chemical composition, thereby greatly influencing its oxidation behavior.

3.2. Microstructural Analysis. Figure 2 shows the microstructure of the intermetallic $\mathrm{Ni}_{75} \mathrm{Al}_{25}$ alloy, where the presence of two phases is observed. The EDXA showed that the dendrite is a phase with high concentration of $\mathrm{Al}$, so that the $\left(\gamma-\gamma^{\prime}\right)$ phase is in the matrix and the $\left(\beta-\gamma^{\prime}\right)$ phase is in the dendrite core as indicated by Hunziker and Kurz [51] and Rosas et al. [52], respectively. During the solidification process, there is no cooling rate sufficiently slow to maintain equilibrium in the melt; that is, there is insufficient time for the composition gradients to be diffusion removed and the dendrites retained [53]. Its formation also may be 


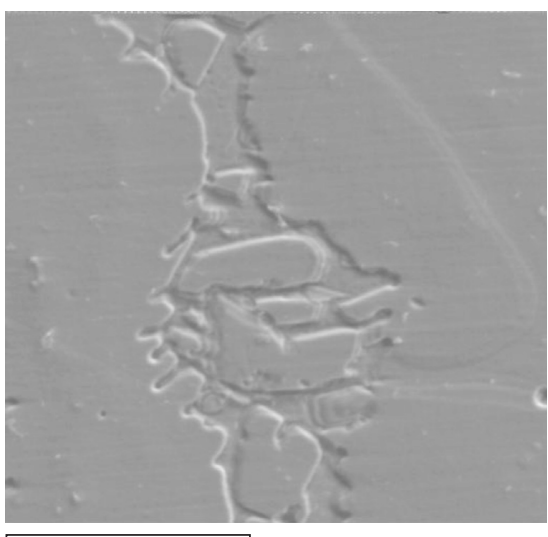

$40 \mu \mathrm{m}$

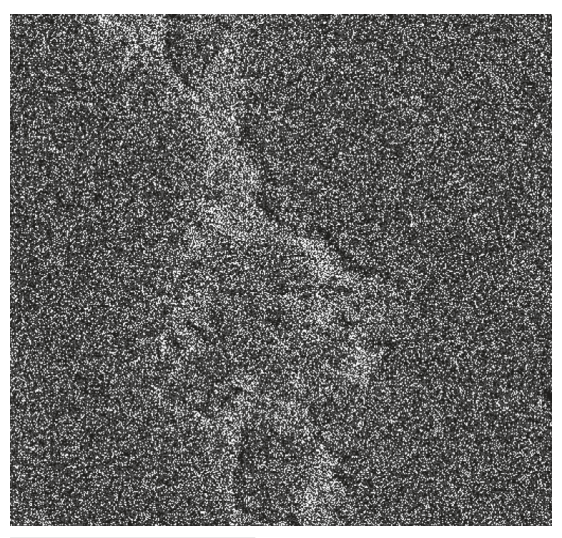

$40 \mu \mathrm{m}$
Aluminum Ka1

(b)

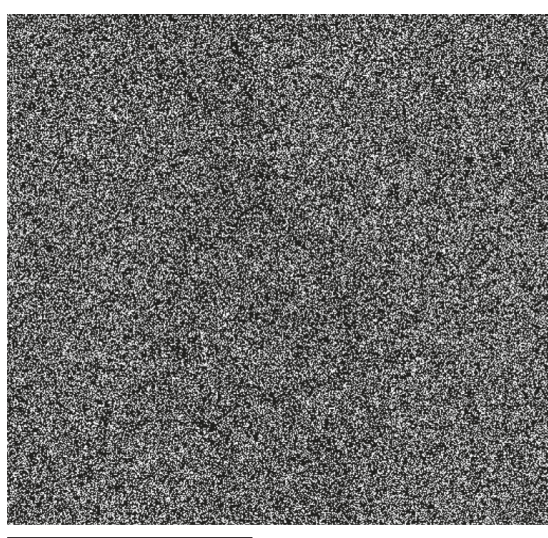

$40 \mu \mathrm{m}$
Nickel Ka1

(c)

FIgURE 2: Microstructure of the $\mathrm{Ni}_{75} \mathrm{Al}_{25}$ intermetallic alloy (a) and EDXA mapping for $\mathrm{Al}$ (b) and Ni (c) of the dendrite structure.

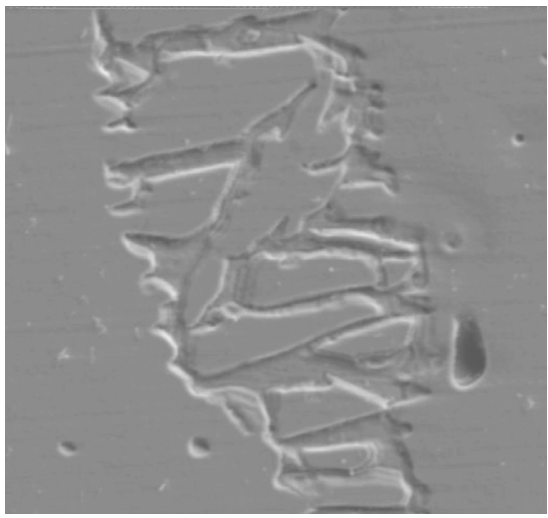

$40 \mu \mathrm{m}$

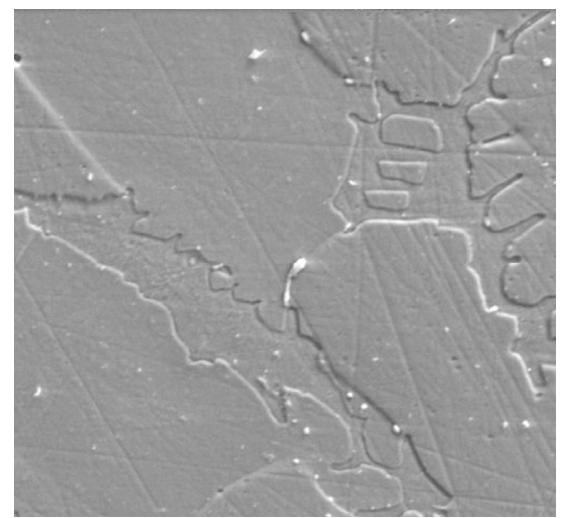

$40 \mu \mathrm{m} \quad$ Mixed

(b)

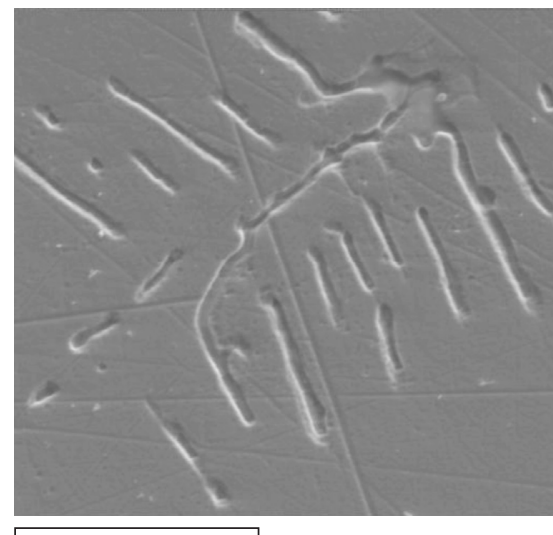

$40 \mu \mathrm{m}$

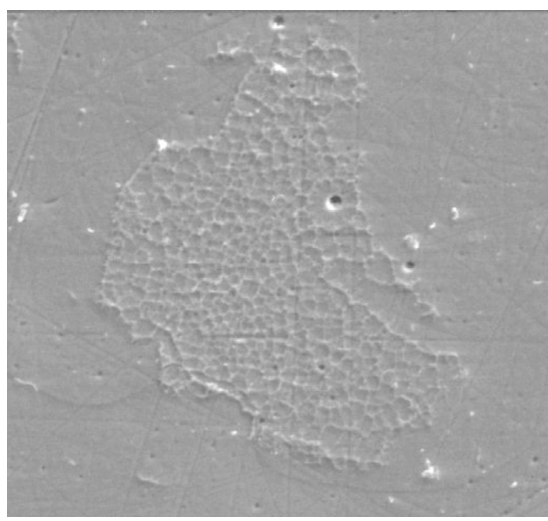

$40 \mu \mathrm{m}$

(c)

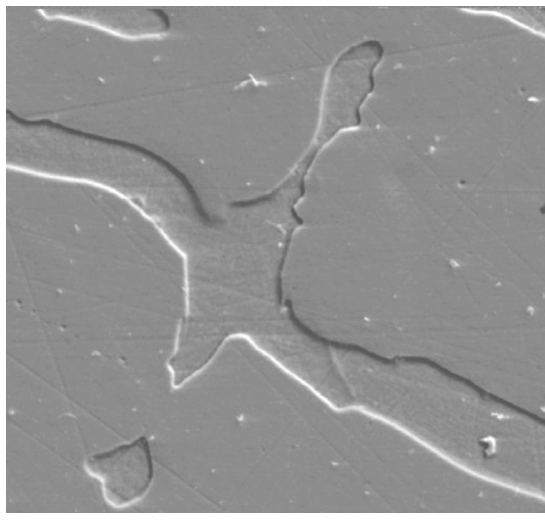

$40 \mu \mathrm{m}$
Mixed

(d)
Mixed

(e)

Figure 3: Microstructure of the $\mathrm{Ni}_{3} \mathrm{Al}$ intermetallic alloys: (a) undoped, (b) $1.0 \% \mathrm{Ag}$, (c) $1.0 \% \mathrm{Au}$, (d) $1.0 \% \mathrm{Pd}$, and (e) $1.0 \% \mathrm{Pt}$.

attributable to the difference between the melting points of the constituent phases. According to Lee et al. [11, 17], when the solidification process begins, it is favored by the formation of the dendritic structures $\left(\beta-\gamma^{\prime}\right)$, and during the cooling process, the $\gamma$-phase decreases while the $\gamma^{\prime}$-phase increases.

Figure 3 shows the microstructure of intermetallic alloys evaluated, and it is observed that there are notable changes in 
TABLE 1: Spaces between secondary arms and space ratio, taking as reference the undoped alloy.

\begin{tabular}{lcc}
\hline Alloy & $\begin{array}{c}\text { Space between } \\
\text { secondary } \\
\text { arms }(\mu \mathrm{m})\end{array}$ & $\begin{array}{c}\text { Space ratio between } \\
\text { secondary arms with } \\
\text { respect to } \mathrm{Ni}_{3} \mathrm{Al}\end{array}$ \\
\hline $\mathrm{Ni}_{3} \mathrm{Al}$ & 47.00 & 1.00 \\
$\mathrm{Ni}_{3} \mathrm{Al}+1 \% \mathrm{Ag}$ & 23.30 & 0.49 \\
$\mathrm{Ni}_{3} \mathrm{Al}+1 \% \mathrm{Au}$ & 73.04 & 1.55 \\
$\mathrm{Ni}_{3} \mathrm{Al}+1 \% \mathrm{Pd}$ & 17.07 & 0.36 \\
$\mathrm{Ni}_{3} \mathrm{Al}+1 \% \mathrm{Pt}$ & 10.24 & 0.22 \\
\hline
\end{tabular}

the microstructure of the doped alloys, which can be explained according to the preferential growth plane of each alloy (Figure 1) and an increase in the solidification rate. The dendrite structure of $\mathrm{Ni}_{75} \mathrm{Al}_{25}$ (Figure 3(a)) has a spacing between secondary arms of $47 \mu \mathrm{m}$, and this value is typical in a conventional solidification process [54]. The space between the secondary arms of the dendrites is inversely related to the cooling rate during the solidification process, which has been correlated according to the following equation [55]:

$$
d_{2}=k v^{-1 / 3},
$$

where $d_{2}$ is the secondary dendrite arm spacing, $v$ is the solidification cooling rate, and $k$ is a constant of the alloy.

Since the solidification cooling rate is inversely proportional to the space between the secondary arms of the dendrites, from Table 1, it can be noticed that the solidification cooling rate in the $\mathrm{Ni}_{75} \mathrm{Al}_{24} \mathrm{Pd}_{1}, \mathrm{Ni}_{75} \mathrm{Al}_{24} \mathrm{Pt}_{1}$, and $\mathrm{Ni}_{75} \mathrm{Al}_{24} \mathrm{Ag}_{1}$ alloys was faster than in the $\mathrm{Ni}_{75} \mathrm{Al}_{25}$ alloy, so that there is a lower space between the secondary dendrite arms; moreover, several directions of dendrites in the $\mathrm{Ni}_{75} \mathrm{Al}_{24} \mathrm{Pt}_{1}$ alloy are congruent with its preferential growth plane. This same affirmation is consistent with the $\mathrm{Ni}_{75} \mathrm{Al}_{24} \mathrm{Pd}_{1}$ alloy with almost only one preferential growth plane. The solidification cooling rate in the $\mathrm{Ni}_{75} \mathrm{Al}_{24} \mathrm{Au}_{1}$ alloy was slower than the undoped alloy such that the dendrites almost disappeared.

It is observed that the addition of $\mathrm{Ag}$ favors an increase in the ratio $\gamma-\gamma^{\prime} / \beta$ due to the reduction in the number and volume of the interdendritic phase (Figure 3(b)). Because of the low solubility of Ag in Ni [56], it is possible to observe the presence of Ag-rich phases. According to Zhou and Guo [57, 58], the presence of Ag at grain boundaries begins during the solidification process since this element segregates at the solid-liquid interface, and at the same time, the Ag solubility decreases causing their precipitation into the grains. The microstructure of the Au-doped intermetallic alloy showed a honeycomb appearance (Figure 3(c)); that is, there is not a tendency to form precipitates as in the case of Ag-doped intermetallic alloy. Sheng et al. [59] found that the effect of addition of $1 \%$ $\mathrm{Au}$ on the microstructure of the NiAl intermetallic alloy causes a grain size reduction and the formation of $\alpha-\mathrm{AlAu}_{2}$ precipitates. It can be assumed that the absence of the $\alpha-\mathrm{AlAu}_{2}$ phase is due to the lower content of $\mathrm{Al}$ in $\mathrm{Ni}_{3} \mathrm{Al}$ compared to that in NiAl. Figures 3(d) and 3(e) show the microstructure of the intermetallic alloy doped with Pd and $\mathrm{Pt}$, respectively. The Pd-doped alloy has dendritic structures of bigger area; however, the relationship $\gamma-\gamma^{\prime} / \beta$ is much greater than in the alloy doped with $\mathrm{Ag}$ and $\mathrm{Au}$, indicating that, at room temperature, the $\gamma-\gamma^{\prime}$ phase is stable. The Pt-doped alloy has very fine dendritic formations in which there is no enrichment of Al. In both cases, a uniform distribution of $\mathrm{Pd}$ and $\mathrm{Pt}$ is observed as in the case of the $\mathrm{Au}$-doped intermetallic alloy. Meng et al. [60] indicate that the addition of $\mathrm{Pd}$ into $\mathrm{Ni}_{3} \mathrm{Al}$ intermetallic alloy generates an increase of delocalized bonding electrons, and this causes a strengthening of the grain boundaries and improves the ductility of the alloy. Furthermore, Li et al. [61, 62], Oquab and Monceau [63], and Zhang et al. [64] mention that Pd plays an important role in stabilizing the $\beta$-phase in $\mathrm{NiAl}$ at high temperatures; the same effect is attributed to the addition of Pt [10]. No precipitates were observed in the interdendritic region of the alloys, indicating that the phases found there are results of a eutectic reaction, contrasting with the work of Lee et al. [11], which presents cell interdendritic microstructures that Hunziker and Kurz [5] defined as peritectic structures.

3.3. Oxidation Kinetics. Figure 4 shows the curves (solid lines) of weight gain per unit area as a function of exposure time during the process of oxidation of the intermetallic alloys between 900 and $1100^{\circ} \mathrm{C}$. The curves were fitted (dashed lines) to an equation of the form [24, 65]:

$$
\Delta m=k t^{n},
$$

where $\Delta m$ is the weight gain per unit area, $k$ is the oxidation rate constant, $n$ is the exponent of velocity, and $t$ is the time of exposure. The values of $k$ and $n$ to fit the experimental results are shown in Table 2. Adjustments were done using a nonlinear least-squares regression method (GaussNewton method) [66]. According to the $n$ values obtained, it can be observed that only at $900^{\circ} \mathrm{C}$, the oxidation kinetics of the $\mathrm{Ni}_{3} \mathrm{Al}$ alloy and the Ag-doped alloy follows a parabolic behavior, all other $n$ values correspond to a subparabolic behavior. The oxidation mechanism of a protective oxide that grows with parabolic kinetics mainly consists of the diffusion of cations from the metal-oxide interface to the oxide-gas interface; however, when the oxidation mechanism approaches to cubic kinetics, some authors attribute this behavior to the oxide grain growth $[67,68]$, although other authors claim that the formation of a protective layer like $\alpha-\mathrm{Al}_{2} \mathrm{O}_{3}$ is more a rule than an exception [69]. An additional characteristic of the subparabolic kinetics is that at the beginning of the oxidation process, a great weight gain is observed with respect to that observed in a parabolic kinetic, being this a characteristic of the transient stage of the oxidation process.

At $900^{\circ} \mathrm{C}, \mathrm{Ag}$ - and Au-doped alloys had the highest weight gain throughout the exposure period with respect to the undoped alloy, whereas Pd- and Pt-doped alloys had the lower weight gain. During first two hours, the Audoped alloy has a significantly greater weight gain, while Ag-, Pd-, and Pt-doped alloys have a similar and slightly higher weight gain than the undoped alloy. At $1000^{\circ} \mathrm{C}$, all doped alloys (except Pd-doped alloy) have the greater 


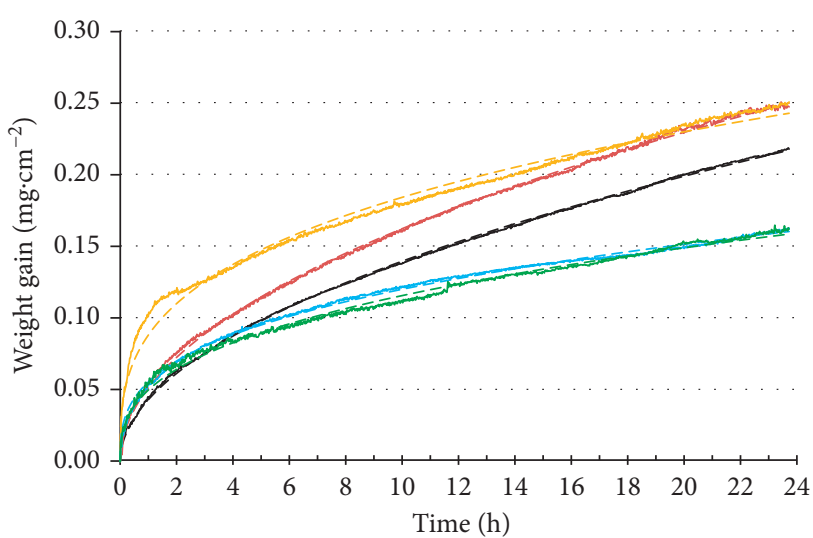

$\begin{array}{ll}-\mathrm{Ni}_{3} \mathrm{~A} 1 & -\mathrm{Ni}_{3} \mathrm{~A} 1+1.0 \% \mathrm{Pd} \\ \mathrm{Ni}_{3} \mathrm{~A} 1+1.0 \% \mathrm{Ag} & -\mathrm{Ni}_{3} \mathrm{~A} 1+1.0 \% \mathrm{Pt} \\ \mathrm{Ni}_{3} \mathrm{~A} 1+1.0 \% \mathrm{Au} & \end{array}$

(a)

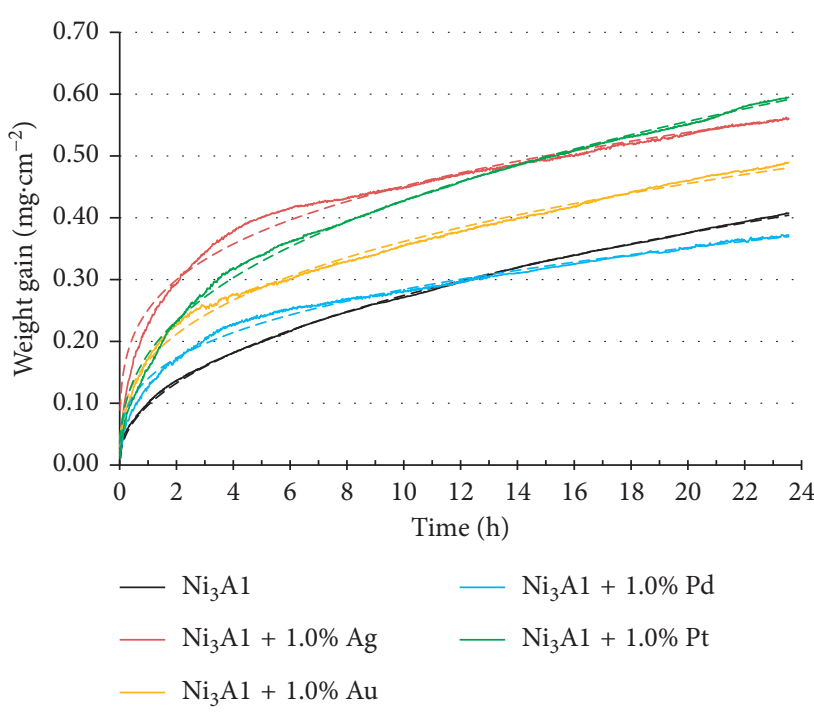

(b)

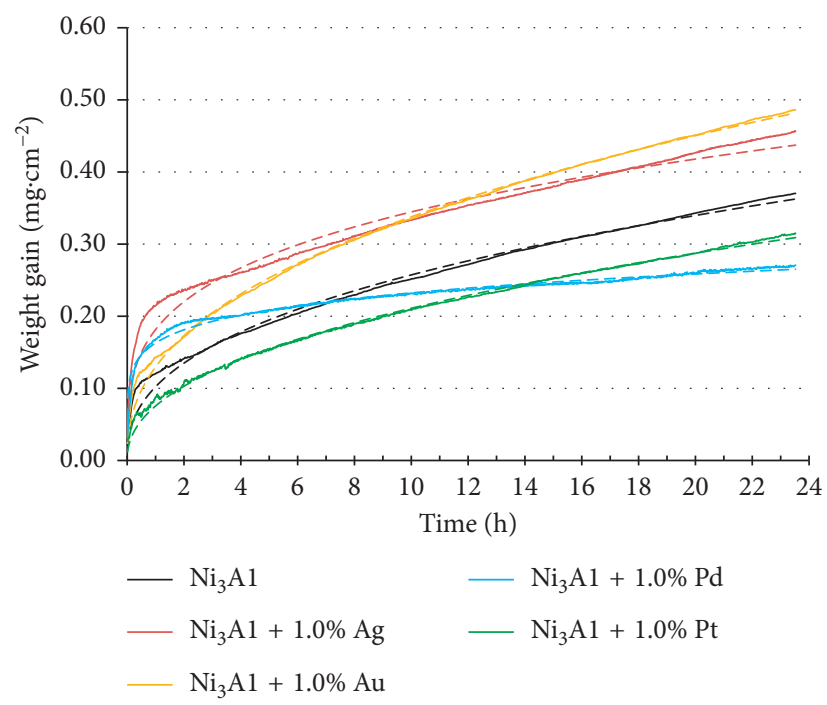

(c)

Figure 4: Weight gain of intermetallic alloys oxidized in $\mathrm{O}_{2}$ at (a) $900^{\circ} \mathrm{C}$, (b) $1000^{\circ} \mathrm{C}$, and (c) $1100^{\circ} \mathrm{C}$.

TABle 2: Values of $k$ and $n$ obtained from the curves of weight gain.

\begin{tabular}{llccccc}
\hline Temperature $\left({ }^{\circ} \mathrm{C}\right)$ & & $\mathrm{Ni}_{3} \mathrm{Al}$ & $\mathrm{Ni}_{3} \mathrm{Al}+1.0 \% \mathrm{Ag}$ & $\mathrm{Ni}_{3} \mathrm{Al}+1.0 \% \mathrm{Au}$ & $\mathrm{Ni}_{3} \mathrm{Al}+1.0 \% \mathrm{Pd}$ & $\mathrm{Ni}_{3} \mathrm{Al}+1.0 \% \mathrm{Pt}^{2}$ \\
\hline \multirow{2}{*}{900} & $k$ & 0.0430 & 0.0513 & 0.0879 & 0.0553 & 0.0497 \\
& $n$ & 0.5106 & 0.4998 & 0.3199 & 0.3350 & 0.3653 \\
\hline \multirow{2}{*}{1000} & $k$ & 0.0971 & 0.2515 & 0.1684 & 0.3070 & 0.1799 \\
& $n$ & 0.4517 & 0.2541 & 0.3323 & 0.1604 & 0.3769 \\
\hline \multirow{2}{*}{1100} & $k$ & 0.1022 & 0.1814 & 0.4156 & 0.1602 & 0.0755 \\
& $n$ & 0.4009 & 0.2785 & 0.4460 \\
\hline
\end{tabular}

weight gain with respect to the undoped alloy, in a decreasing order of Au-, Ag-, and Pt-doped alloys. This behavior may be because the doped alloys stabilize the $\theta-\mathrm{Al}_{2} \mathrm{O}_{3}$ phase and therefore reduce the $\alpha-\mathrm{Al}_{2} \mathrm{O}_{3}$ phase transformation as Pt does according to Cadoret et al. [70] and Hayashi and Gleeson [71]. The $\theta-\mathrm{Al}_{2} \mathrm{O}_{3}$ phase generates more pathways for diffusion because of its smaller grain size compared to $\alpha-\mathrm{Al}_{2} \mathrm{O}_{3}$ phase. The $k$ values at $1000^{\circ} \mathrm{C}$ show magnitudes that explain the high increase in weight gain for doped alloys. At $1100^{\circ} \mathrm{C}$, there is a clear grouping in 


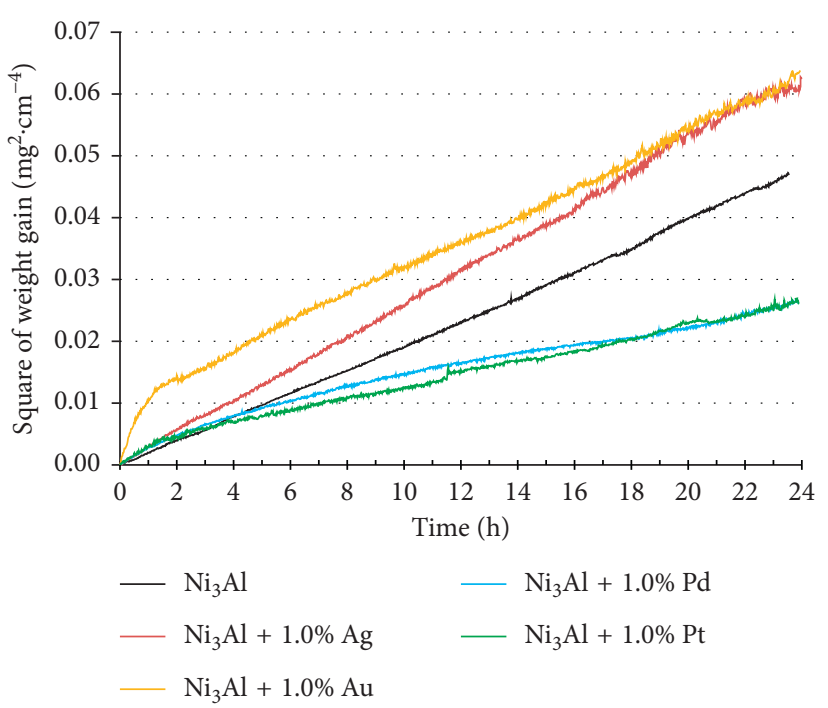

(a)

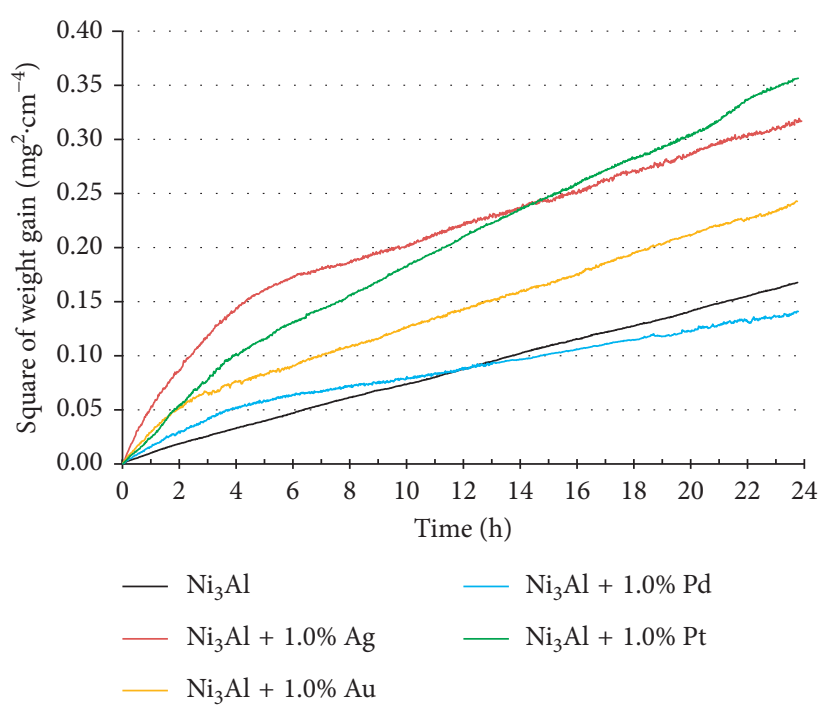

(b)

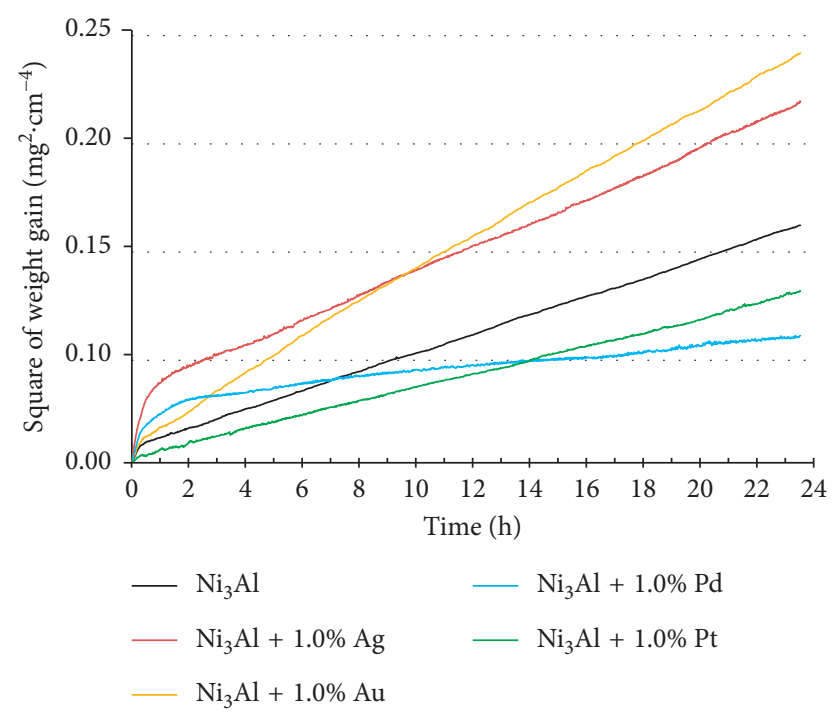

(c)

Figure 5: Square weight gain versus time of exposure of intermetallic alloys oxidized in $\mathrm{O}_{2}$ at (a) $900^{\circ} \mathrm{C}$, (b) $1000^{\circ} \mathrm{C}$, and (c) $1100^{\circ} \mathrm{C}$.

terms of weight gain between the Pd- and Pt-doped alloys (lowest) and the Ag- and Au-doped alloys (higher) compared to undoped alloy, similar as at $900^{\circ} \mathrm{C}$. The Pt-doped alloy has the lower weight gain than the undoped alloy throughout the exposure period, while the Pd-doped alloy has a higher weight gain than the undoped alloy only in the first six hours. All alloys except Pd-doped alloy have a remarkably high weight gain in the first hour.

The weight gain curves of Figure 4 give an impression about the effect of the addition of noble metals in the oxidation process, but it is also necessary to know the rate of oxidation. Considering strictly a parabolic behavior $n=0.5$, for comparative purposes (2) can be rewritten as

$$
\Delta m^{2}=k_{p} t
$$

where $k_{p}$ is the parabolic rate constant. The linearity of (3) allows graphically displaying and estimating the $k_{p}$ value considering the slope of the $\Delta m^{2}-t$ relationship. In Figure 5, changes in the parabolic rate constant showing two $k_{p}$ values can be identified, the first $k_{p}$ value being greater than the second one; this is due to the fact that it is mathematically forcing a curve with a subparabolic behavior to be adjusted to a parabolic behavior [69], so the $k_{p}$ value that will be taken into account to characterize the oxidation process will be that of the second slope which is presented in Table 3.

At $900^{\circ} \mathrm{C}$, undoped and Ag-doped alloys show a constant $k_{p}$ value throughout the exposure period. The $k_{p}$ value of $\mathrm{Pd}$ and Pt-doped alloys is similar, and it is lower than that for the undoped alloy. At $1000^{\circ} \mathrm{C}$, the $k_{p}$ value of the $\mathrm{Au}$-doped 
TABLE 3: Values of $k_{p}$ obtained from slopes of Figure 5.

\begin{tabular}{lccccc}
\hline Temperature $\left({ }^{\circ} \mathrm{C}\right)$ & $\mathrm{Ni}_{3} \mathrm{Al}$ & $\mathrm{Ni}_{3} \mathrm{Al}+1.0 \% \mathrm{Ag}$ & $\mathrm{Ni}_{3} \mathrm{Al}+1.0 \% \mathrm{Au}$ & $\mathrm{Ni}_{3} \mathrm{Al}+1.0 \% \mathrm{Pd}$ & $\mathrm{Ni}{ }_{3} \mathrm{Al}+1.0 \% \mathrm{Pt}$ \\
\hline 900 & 0.0019 & 0.0026 & 0.0022 & 0.0010 & 0.0010 \\
1000 & 0.0072 & 0.0082 & 0.0085 & 0.0045 & 0.0136 \\
1100 & 0.0054 & 0.0071 & 0.0095 & 0.0016 & 0.0040 \\
\hline
\end{tabular}

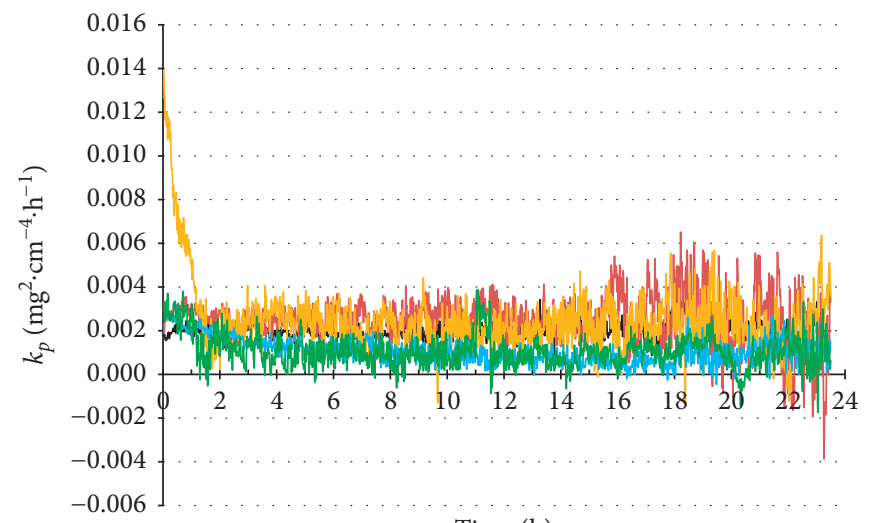

Time (h)

$$
\begin{array}{ll}
-\mathrm{Ni}_{3} \mathrm{Al} & -\mathrm{Ni}_{3} \mathrm{Al}+1.0 \% \mathrm{Pd} \\
-\mathrm{Ni}_{3} \mathrm{Al}+1.0 \% \mathrm{Ag} & -\mathrm{Ni}_{3} \mathrm{Al}+1.0 \% \mathrm{Pt} \\
-\mathrm{Ni}_{3} \mathrm{Al}+1.0 \% \mathrm{Au} &
\end{array}
$$

(a)

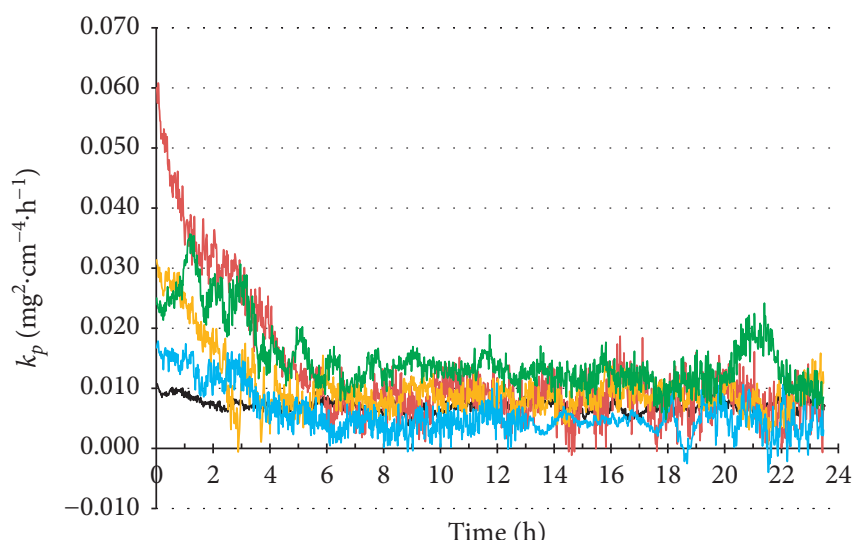

$$
\begin{array}{ll}
-\mathrm{Ni}_{3} \mathrm{Al} & -\mathrm{Ni}_{3} \mathrm{Al}+1.0 \% \mathrm{Pd} \\
-\mathrm{Ni}_{3} \mathrm{Al}+1.0 \% \mathrm{Ag} & -\mathrm{Ni}_{3} \mathrm{Al}+1.0 \% \mathrm{Pt} \\
-\mathrm{Ni}_{3} \mathrm{Al}+1.0 \% \mathrm{Au} &
\end{array}
$$

(b)

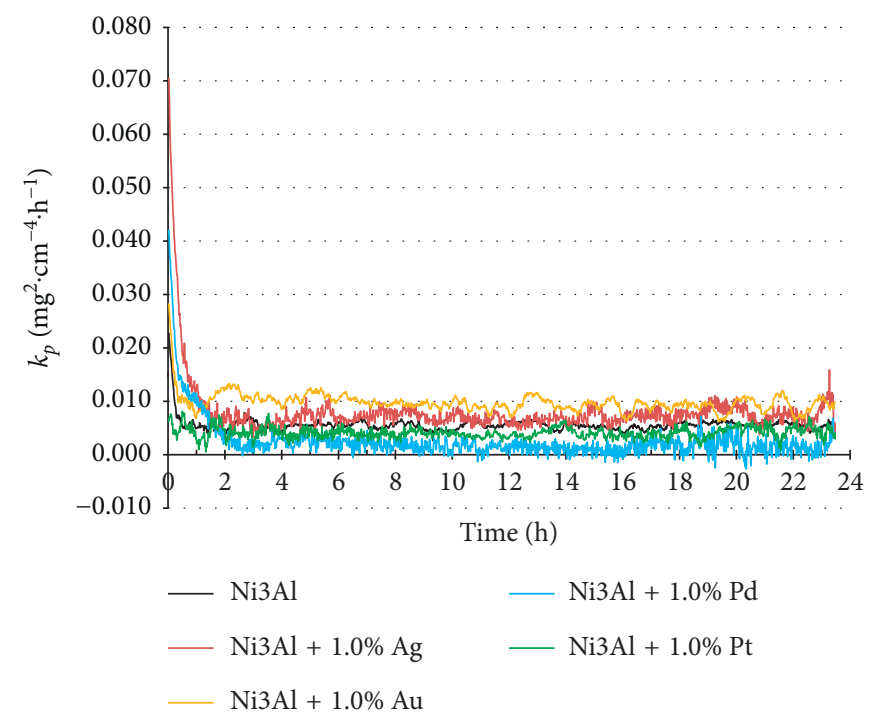

(c)

Figure 6: Instantaneous $k_{p}$ versus time for the intermetallic alloys oxidized at (a) $900^{\circ} \mathrm{C}$, (b) $1000^{\circ} \mathrm{C}$, and (c) $1100^{\circ} \mathrm{C}$.

TABLE 4: Average values of instantaneous $k_{p}$ from Figure 6.

\begin{tabular}{lccccc}
\hline $\mathrm{T}\left({ }^{\circ} \mathrm{C}\right)$ & $\mathrm{Ni}_{3} \mathrm{Al}$ & $\mathrm{Ni}_{3} \mathrm{Al}+1 \% \mathrm{Ag}$ & $\mathrm{Ni}_{3} \mathrm{Al}+1 \% \mathrm{Au}$ & $\mathrm{Ni}_{3} \mathrm{Al}+1 \% \mathrm{Pd}$ & 0.0011 \\
\hline 900 & 0.0020 & 0.0026 & 0.0027 & 0.0059 & 0.0011 \\
1000 & 0.0070 & 0.0132 & 0.0102 & 0.0032 & 0.0149 \\
1100 & 0.0058 & 0.0088 & 0.0101 & $\mathrm{Ni}$ & 0.0041 \\
\hline
\end{tabular}




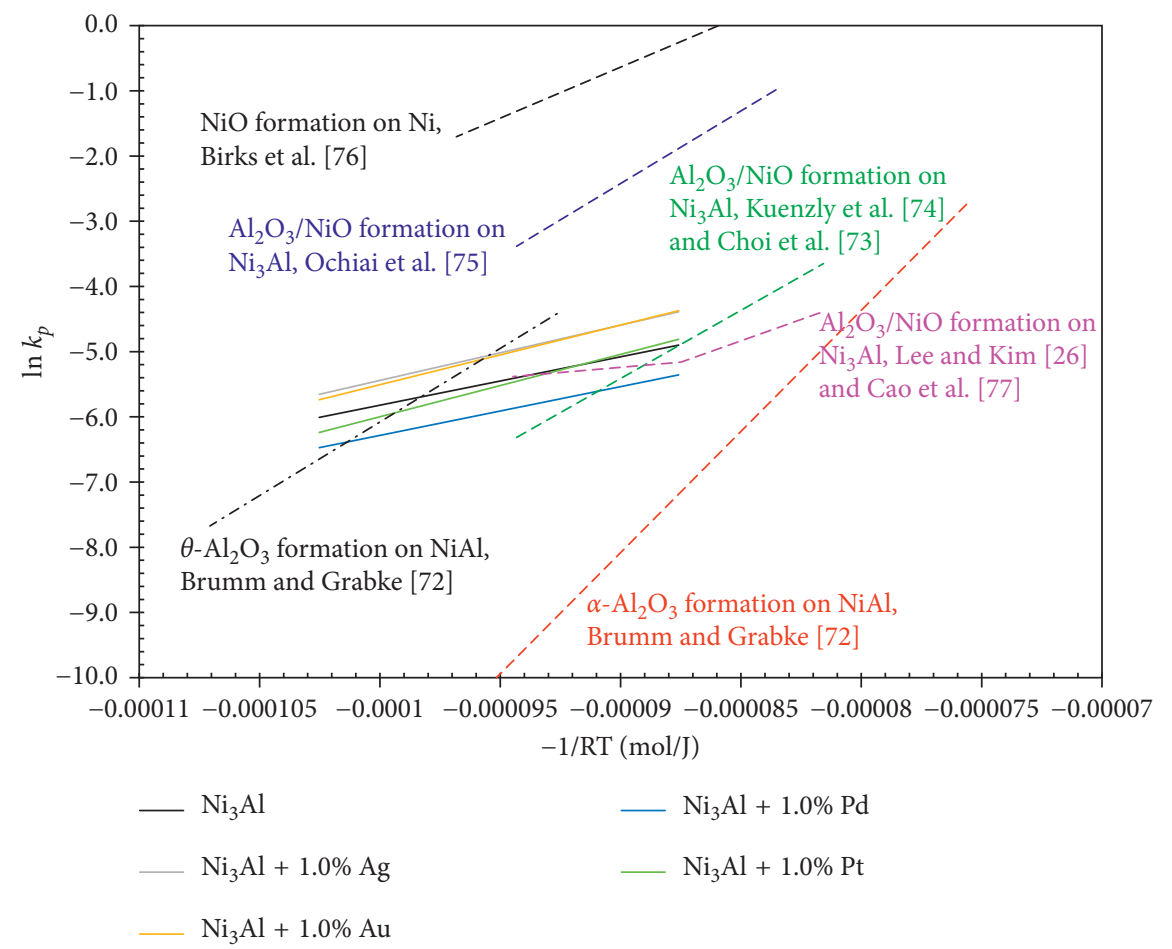

FIGURE 7: Arrhenius graph showing the $k_{p}$ variation in function of temperature.

TABLE 5: Values of $k_{0}$ and $Q$ obtained from the Arrhenius graph.

\begin{tabular}{lccccc}
\hline & $\mathrm{Ni}_{3} \mathrm{Al}$ & $\mathrm{Ni}_{3} \mathrm{Al}+1.0 \% \mathrm{Ag}$ & $\mathrm{Ni}_{3} \mathrm{Al}+1.0 \% \mathrm{Au}$ & $\mathrm{Ni}_{3} \mathrm{Al}+1.0 \% \mathrm{Pd}$ & $\mathrm{Ni} \mathrm{Al}+1.0 \% \mathrm{Pt}$ \\
\hline $\ln \left(k_{0}\right)$ & 1.6031 & 3.0341 & 3.6400 & 1.1934 & 3.5693 \\
$Q(\mathrm{~kJ} / \mathrm{mol})$ & 74.2443 & 84.7525 & 91.4718 & 74.7778 & 95.6762 \\
\hline
\end{tabular}

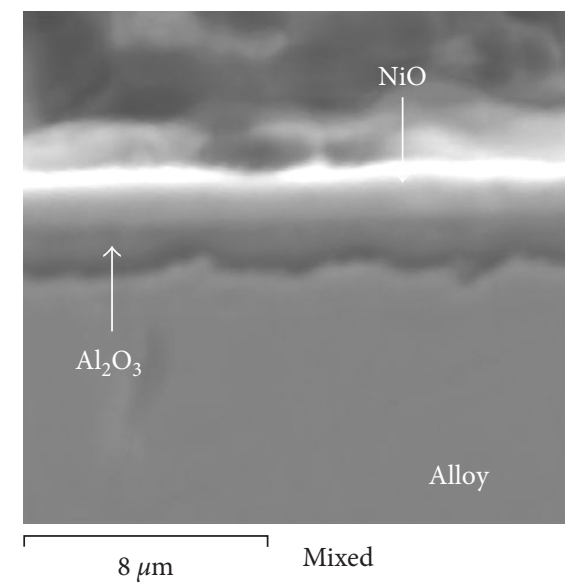

(a)

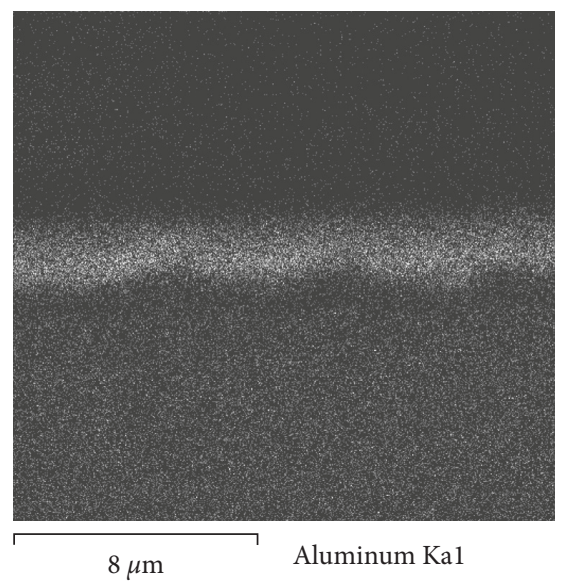

(b)

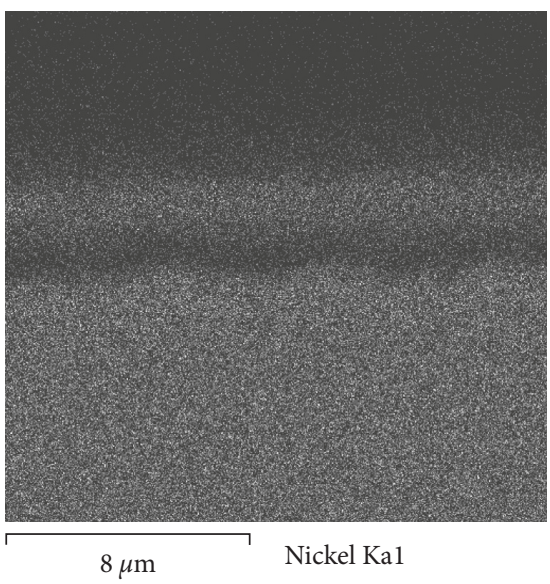

(c)

Figure 8: SEM micrograph (a) and mapping elements (b, c) of the scale formed onto $\mathrm{Ni}_{3} \mathrm{Al}$ at $900^{\circ} \mathrm{C}$.

alloy decreases at three hours after starting the test, the $k_{p}$ value of $\mathrm{Ag}, \mathrm{Pd}$, and Pt doped alloys decreases at four hours after starting the test, while for the undoped alloy, its $k_{p}$ value remains constant. At $1100^{\circ} \mathrm{C}$, the $k_{p}$ value of the undoped and doped alloys decrease at the first half an hour after starting the test, except the Pt-doped alloy, for which the $k_{p}$ value remains constant. In most alloys, at all temperatures, it is observed at most only one change in $k_{p}$, except the Pd-doped alloy at $1100^{\circ} \mathrm{C}$ with two changes: half an hour and two hours after starting the test. At $1000^{\circ} \mathrm{C}$, the $k_{p}$ value of the 


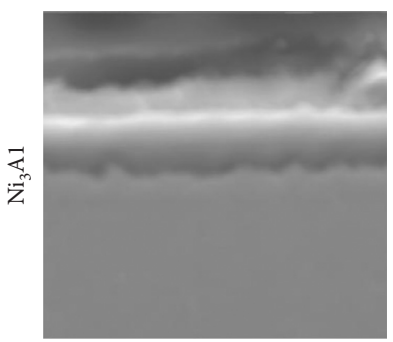

$8 \mu \mathrm{m} \quad$ Mixed

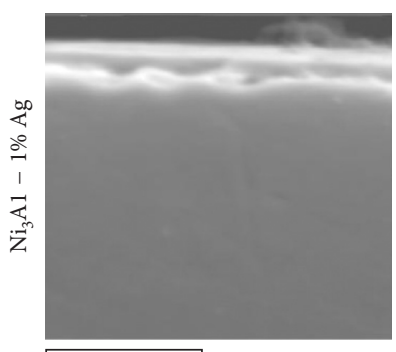

$8 \mu \mathrm{m}$ Mixed
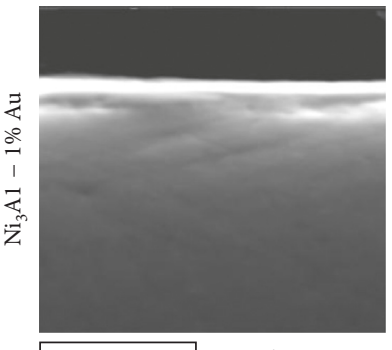

$8 \mu \mathrm{m} \quad$ Mixed

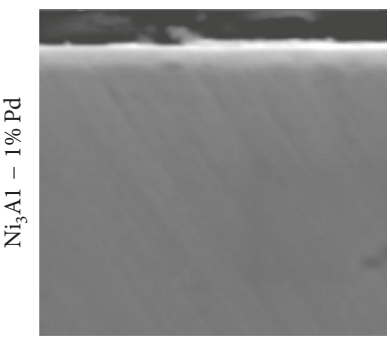

$8 \mu \mathrm{m} \quad$ Mixed

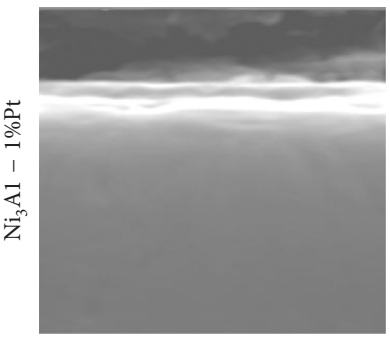

$8 \mu \mathrm{m}$ Mixed

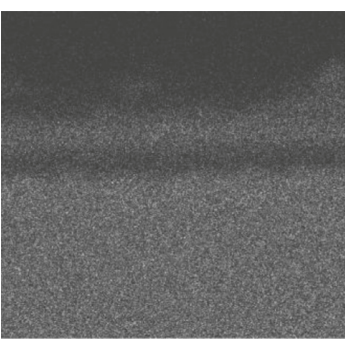

$8 \mu \mathrm{m}$ Nickel Kal

(a)

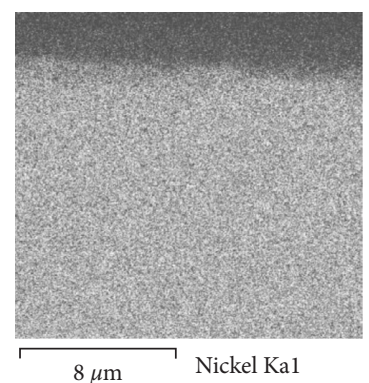

(b)

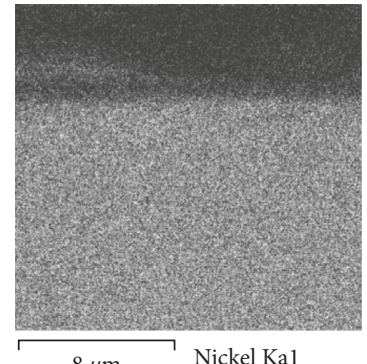

(c)

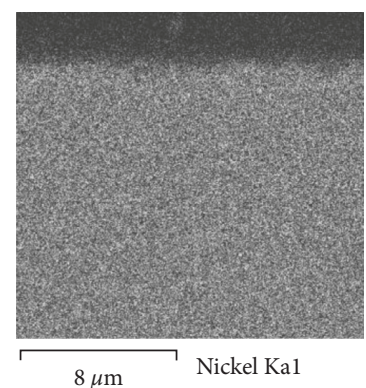

(d)

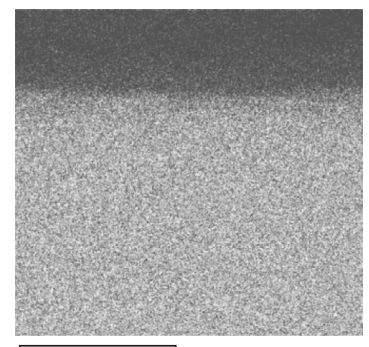

Nickel Kal

)
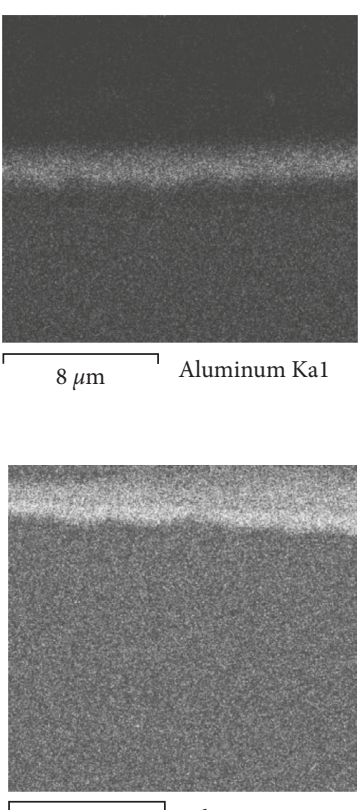

$8 \mu \mathrm{m}$

Aluminum Kal
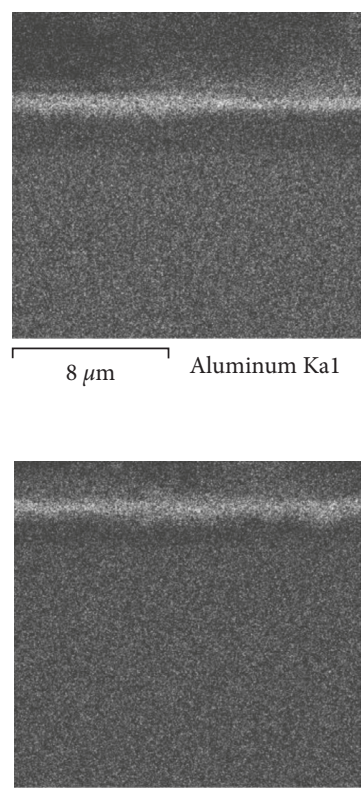

$8 \mu \mathrm{m}$

Aluminum Kal

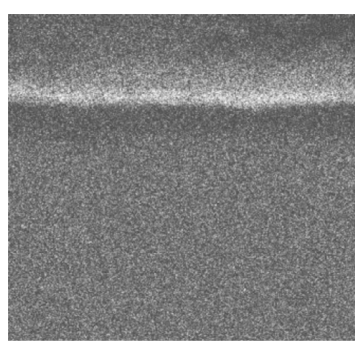

$8 \mu \mathrm{m} \quad$ Aluminum Kal

Figure 9: Cross section of intermetallic alloys and mapping elements after oxidation at $900^{\circ} \mathrm{C}$ : (a) $\mathrm{Ni}_{3} \mathrm{Al}$, (b) $\mathrm{Ag}$-doped alloy, (c) Au-doped alloy, (d) Pd-doped alloy, (e) Pt-doped alloy. 


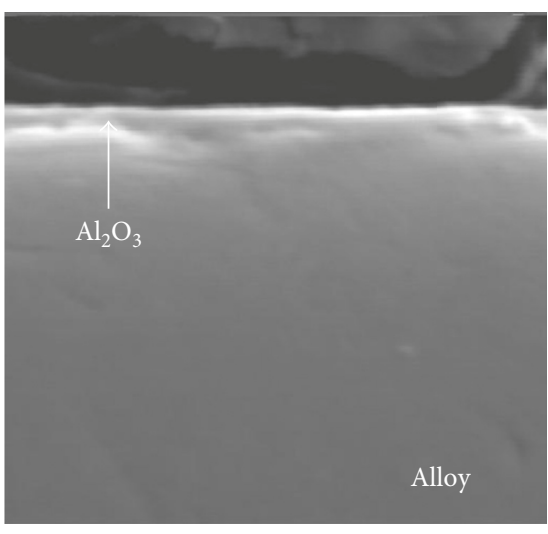

$8 \mu \mathrm{m}$ Mixed

(a)

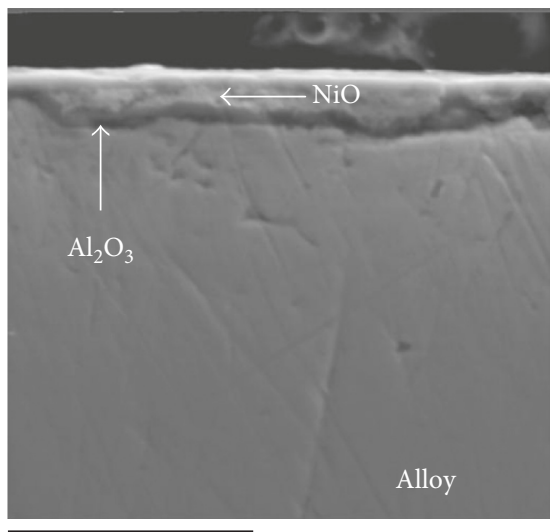

$20 \mu \mathrm{m}$ Mixed

(d)

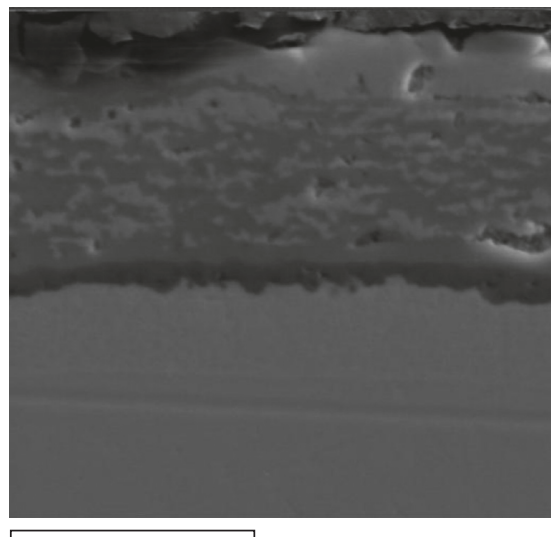

$20 \mu \mathrm{m}$

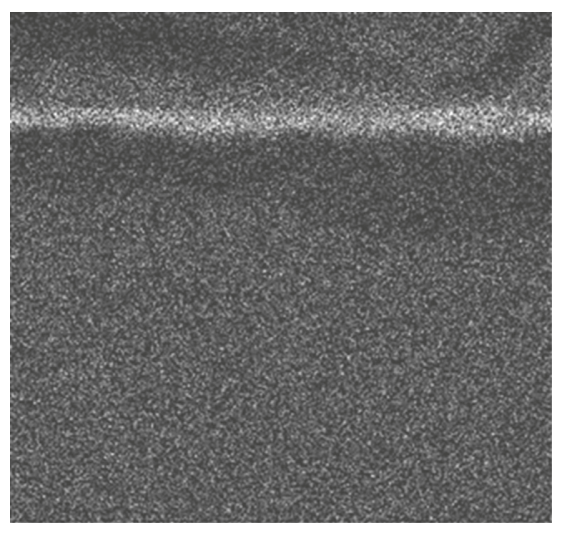

$8 \mu \mathrm{m}$

(b)

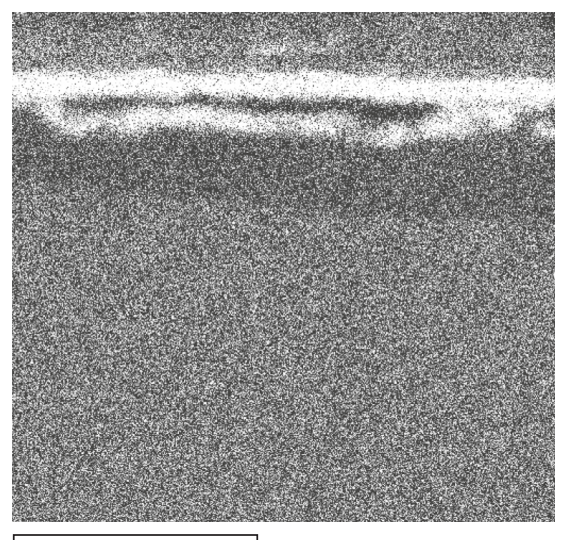

$20 \mu \mathrm{m}$

(e)

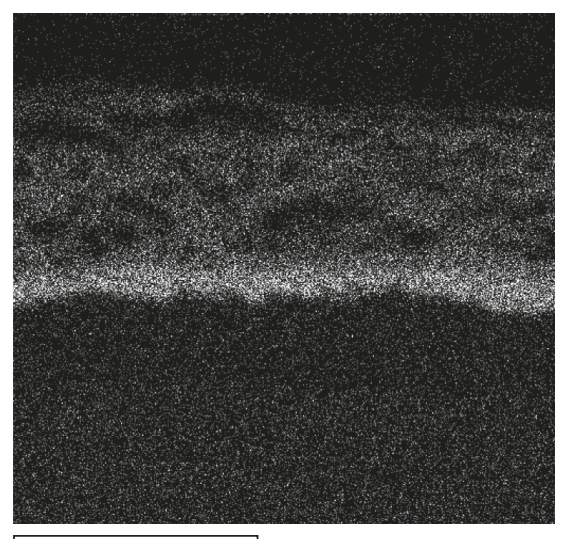

$20 \mu \mathrm{m}$

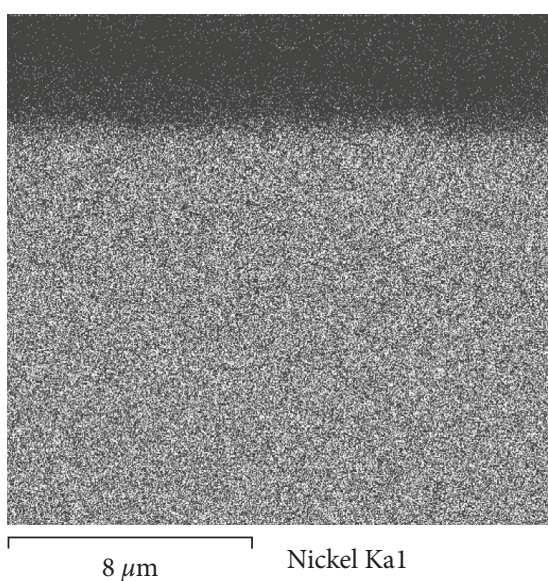

(c)

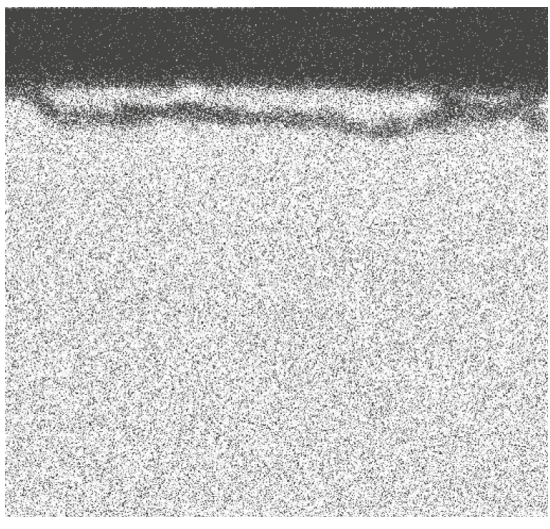

$20 \mu \mathrm{m}$

Nickel Ka1

(f)

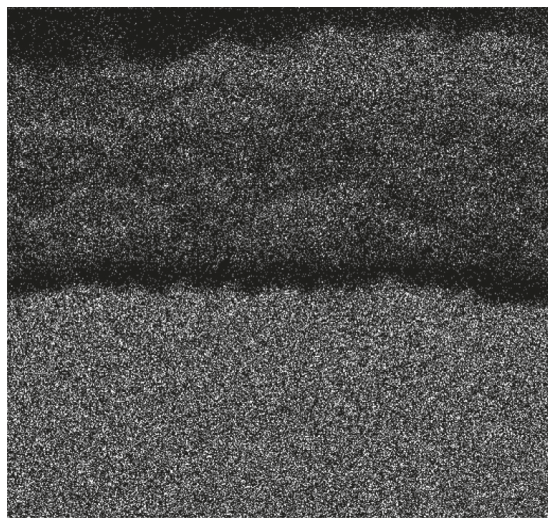

$20 \mu \mathrm{m}$

Nickel Ka1

(i)

(g)

(h)

Figure 10: SEM micrograph and mapping elements: (a-c) Pd-doped alloy $\left(900^{\circ} \mathrm{C}\right),(\mathrm{d}-\mathrm{f})$ Pt-doped alloy $\left(1000^{\circ} \mathrm{C}\right)$, and $(\mathrm{g}-\mathrm{i}) \mathrm{Ag}-\mathrm{doped}$ alloy $\left(1100^{\circ} \mathrm{C}\right)$.

Au-doped alloy decreases at three hours after starting the test, and for Ag-, Pd-, and Pt-doped alloys, the $k_{p}$ value decreases at four hours after starting the test, while for the undoped alloy, its $k_{p}$ value remains constant. At $1100^{\circ} \mathrm{C}$, the $k_{p}$ value of all alloys (except $\mathrm{Pt}$ ) decreases after $30 \mathrm{~min}$, and for Pt-doped alloy, the $k_{p}$ value remains constant.

When it is not possible to obtain accurate measurement from the slopes, it is necessary to consider the average of the 


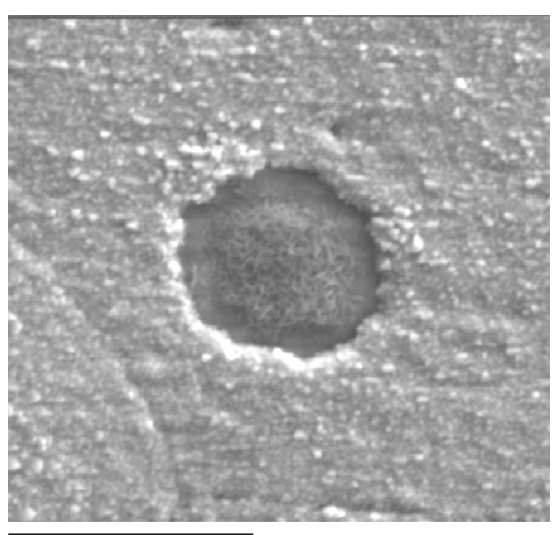

$20 \mu \mathrm{m}$

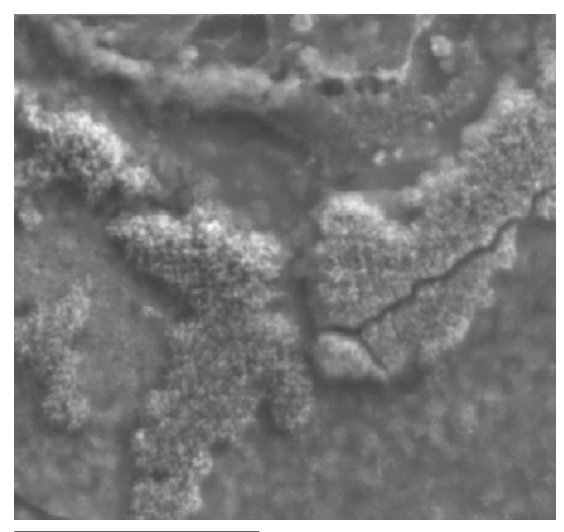

$20 \mu \mathrm{m}$

(a)

(b)

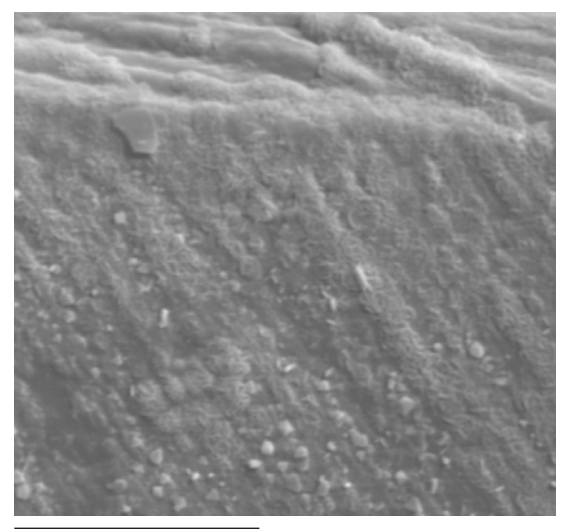

$20 \mu \mathrm{m}$

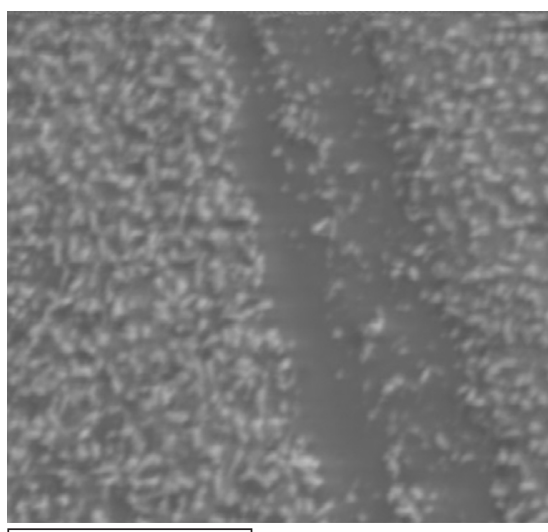

$20 \mu \mathrm{m}$

(c)

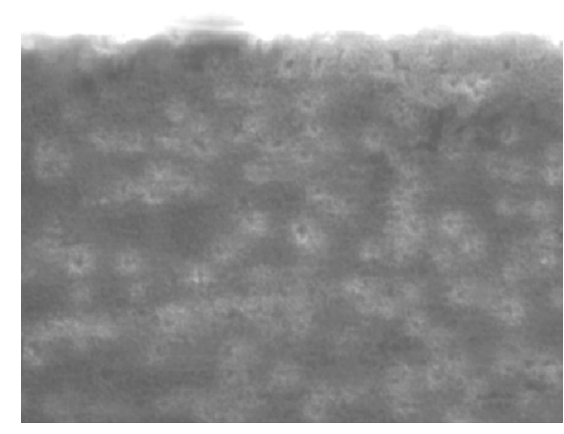

$20 \mu \mathrm{m}$

(d)

(e)

FIGURE 11: SEM micrographs showing the surface morphology of the oxide scales at $900^{\circ} \mathrm{C}$ : (a) $\mathrm{Ni}_{3} \mathrm{Al},(\mathrm{b}) \mathrm{Ni}_{3} \mathrm{Al}+1.0 \% \mathrm{Ag},(\mathrm{c}) \mathrm{Ni}{ }_{3} \mathrm{Al}+1.0 \%$ $\mathrm{Au}$, (d) $\mathrm{Ni}_{3} \mathrm{Al}+1.0 \% \mathrm{Pd}$, and (e) $\mathrm{Ni}_{3} \mathrm{Al}+1.0 \% \mathrm{Pt}$.

instantaneous parabolic constants, which results in differentiating (3) versus time [65],

$$
\frac{d\left(\Delta m^{2}\right)}{d t}=k_{p}
$$

The instantaneous parabolic constant $\left(k_{p}\right)$ of the oxidation tests is shown in Figure 6. This type of representation of the experimental data provides more information regarding the evolution of oxidation rates. At $900^{\circ} \mathrm{C}$ (Figure 6(a)), in the first two hours, the $k_{p}$ values of the Au-doped alloy decrease seven times its equilibrium value, while in the Pd-and Pt-doped alloys, the $k_{p}$ values decrease two times their equilibrium value; on the other hand, the Ag-doped alloy and undoped alloy maintain a constant rate. At $1000^{\circ} \mathrm{C}$ (Figure $6(\mathrm{~b})$ ), it is observed that the values of the instantaneous parabolic constant $k_{p}$ of doped alloys tend to decrease in the first 6 hours, and then they remain constant, and for the undoped alloy, the $k_{p}$ values remain constant. For the Ag-doped alloy, its $k_{p}$ value decreases six times its equilibrium value, and for other doped-alloys, their $k_{p}$ values decrease two times their equilibrium value. Finally, at $1100^{\circ} \mathrm{C}$ (Figure 6(c)), the
Pt-doped alloy shows a stable behavior, and the other alloys show a fast decrease in their $k_{p}$ values in the first hour.

In order to visualize the effect of the temperature on the rate constants, it is necessary to determine the activation energy of the oxidation process from the Arrhenius equation.

$$
\ln k_{p}=\ln k_{0}-Q \cdot(R T)^{-1},
$$

where $Q$ is the activation energy, $R$ is the universal gas constant, $T$ is the temperature, $k_{p}$ is the rate constant, and $k_{0}$ is the preexponential factor. Plotting $\ln k_{p}$ versus $-(R T)^{-1}$ from the slope of the lines, the $Q$ value can be determined. Perez et al. [65] suggest assuming a parabolic kinetics in the whole temperature range; therefore, the average value of instantaneous $k_{p}$ from Figure 6 was calculated. Table 4 shows the average values of instantaneous $k_{p}$.

In order to compare the results of this work, Figure 7 shows the instantaneous $k_{p}$ values obtained along with those reported in other studies. At 900 and $1000^{\circ} \mathrm{C}$, the $k_{p}$ values of both doped and undoped alloys tend to $k_{p}$ values where the formation of the $\theta-\mathrm{Al}_{2} \mathrm{O}_{3}$ phase may be possible in $\mathrm{NiAl}$ as reported by Brumm and Grabke [72]. At $1100^{\circ} \mathrm{C}$, the $k_{p}$ values are concentrated at a point between the formation of 


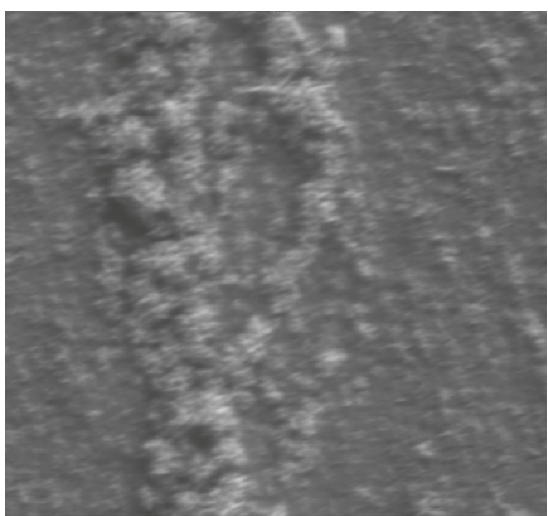

$20 \mu \mathrm{m}$

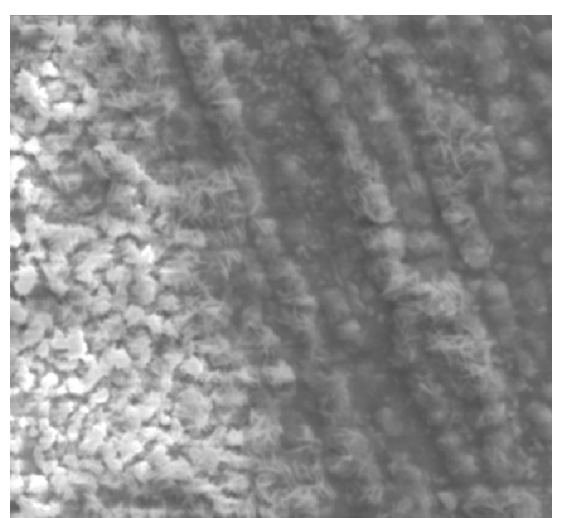

$20 \mu \mathrm{m}$ (a)

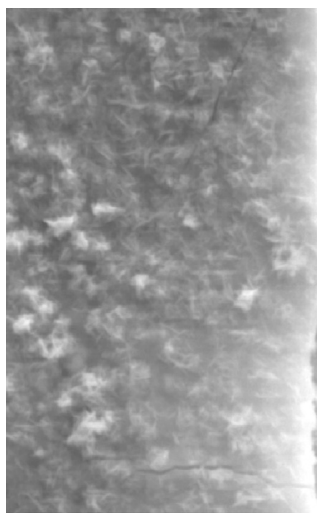

$20 \mu \mathrm{m}$

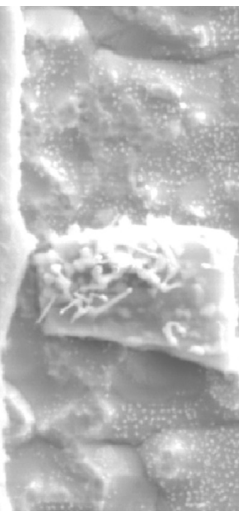

(d)

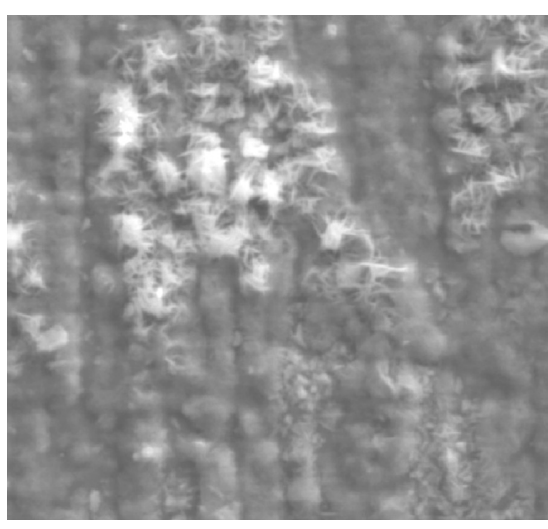

$20 \mu \mathrm{m}$

(c) (b)

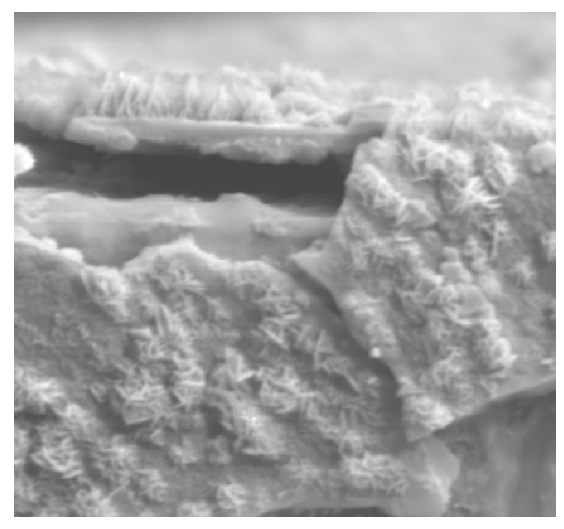

$20 \mu \mathrm{m}$

(e)

FiguRE 12: SEM micrographs showing the surface morphology of the oxide scales at $1000^{\circ} \mathrm{C}$ : (a) $\mathrm{Ni}_{3} \mathrm{Al}$, (b) $\mathrm{Ni}_{3} \mathrm{Al}+1.0 \% \mathrm{Ag},(\mathrm{c}) \mathrm{Ni} \mathrm{Al}_{3} \mathrm{Al}+1.0 \%$ $\mathrm{Au},(\mathrm{d}) \mathrm{Ni}_{3} \mathrm{Al}+1.0 \% \mathrm{Pd}$, and (e) $\mathrm{Ni}_{3} \mathrm{Al}+1.0 \% \mathrm{Pt}$.

$\theta-\mathrm{Al}_{2} \mathrm{O}_{3}$ and $\alpha-\mathrm{Al}_{2} \mathrm{O}_{3}$; an explanation for this behavior could be that, at this temperature, the stability of the $\alpha-\mathrm{Al}_{2} \mathrm{O}_{3}$ begins [18] and this tends to decrease the weight gain [70, 71]. At $900^{\circ} \mathrm{C}$ and $1000^{\circ} \mathrm{C}$, the $k_{p}$ value of the undoped alloy is similar to results reported by Lee and Kim [26] and Choi et al. [73], and at $1100^{\circ} \mathrm{C}$, it is similar to results of Kuenzly et al. [74]. The Pt-doped alloy has $k_{p}$ values similar to the undoped alloy, Ag- and Au-doped alloys have higher $k_{p}$ values, and the Pd-doped alloy has lower $k_{p}$ values.

Activation energy is an important parameter that characterizes the predominant oxidation mechanism [75]; for example, the results presented by Ochiai et al. [75] and Kuenzly et al. [74] suggest that, in both cases, the oxidation mechanism is similar, although the experimental conditions were different, that is, cyclic oxidation tests and continuous oxidation tests. On the other hand, analyzing the results for the formation of $\alpha-\mathrm{Al}_{2} \mathrm{O}_{3}$ scale [72] and $\mathrm{NiO}$ scale [76], it is observed that the preexponential factor is inversely proportional to the protective capacity of the protective oxide. Table 5 shows the activation energies and preexponential factors obtained from the Arrhenius graph (Figure 7). The activation energy value of $\mathrm{Ni}_{3} \mathrm{Al}$ is similar to those values reported by Lee and Kim [26] and Cao et al. [77], but almost three times lower than that reported by other authors [73, 74]. This difference is because the intermetallic alloy used in this study was not thermally treated. Activation energy values of the doped alloys show that the additions of the noble elements affect the $\mathrm{Ni}_{3} \mathrm{Al}$ oxidation mechanism in the following order: $\mathrm{Pt}>\mathrm{Au}>\mathrm{Ag}>\mathrm{Pd}$. On the other hand, the Pd-doped alloy showed the lowest value of the preexponential factor.

3.4. SEM Analysis. SEM analysis showed that the oxide scale formed on all alloys had nonuniform thicknesses. In the case of $\mathrm{Ni}_{3} \mathrm{Al}$, the average thicknesses observed were between 2.44 and $2.86 \mu \mathrm{m}$ in the temperature range studied. At $900^{\circ} \mathrm{C}$ (Figure 8), a double-layer oxide was developed, an outer Ni-rich layer and an internal Al-rich layer, with similar thicknesses. Other authors have described similar results [78]. However, at higher temperatures, only the presence of an Al-rich oxide was detected.

In general, the thickness of the oxide layer developed onto doped alloys was lower than that observed onto $\mathrm{Ni}_{3} \mathrm{Al}$. 


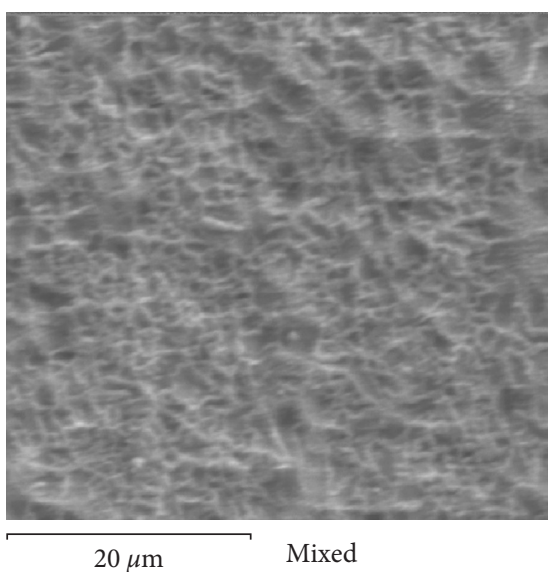

(a)

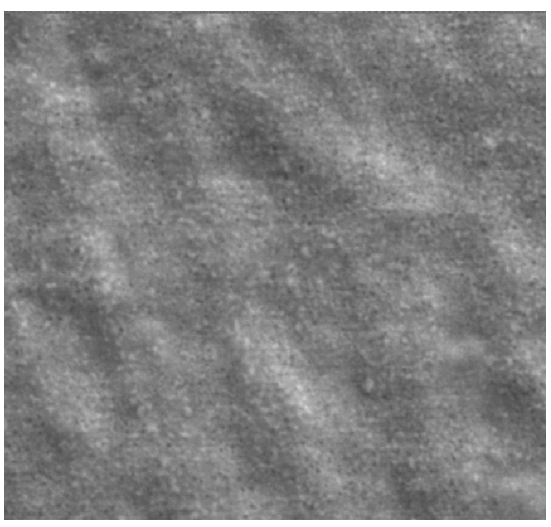

$20 \mu \mathrm{m}$

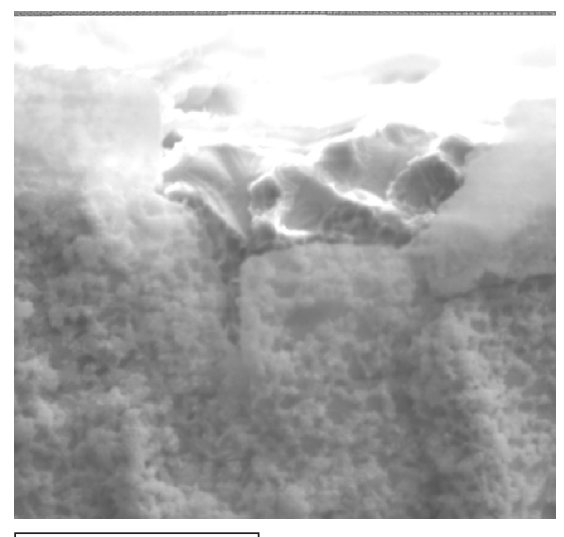

$20 \mu \mathrm{m}$

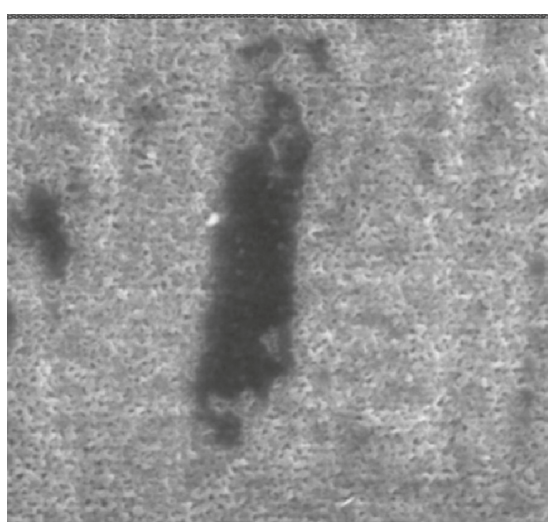

$20 \mu \mathrm{m}$

(b)

(c)

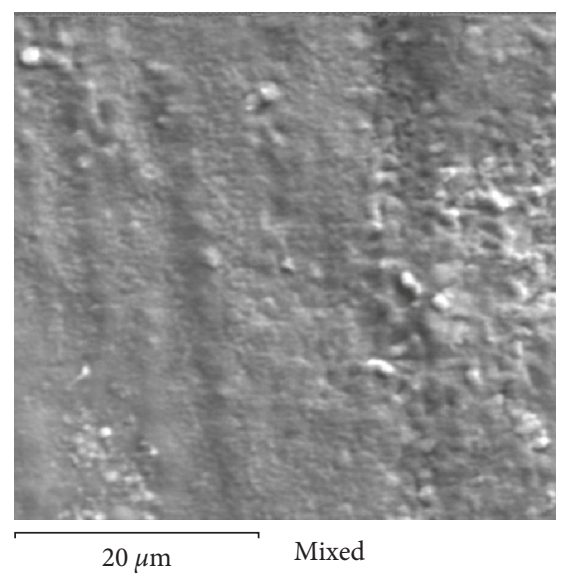

(e)

Figure 13: SEM micrographs showing the surface morphology of the oxide scales at $1100^{\circ} \mathrm{C}$ : (a) $\mathrm{Ni}_{3} \mathrm{Al},(\mathrm{b}) \mathrm{Ni}_{3} \mathrm{Al}+1.0 \% \mathrm{Ag},(\mathrm{c}) \mathrm{Ni}{ }_{3} \mathrm{Al}+1.0 \%$ $\mathrm{Au}$, (d) $\mathrm{Ni}_{3} \mathrm{Al}+1.0 \% \mathrm{Pd}$, and (e) $\mathrm{Ni}_{3} \mathrm{Al}+1.0 \% \mathrm{Pt}$.

At $900^{\circ} \mathrm{C}$, the average thicknesses were between 0.98 and $1.5 \mu \mathrm{m}$, at $1000^{\circ} \mathrm{C}$, between 2.13 and $2.20 \mu \mathrm{m}$ (except the Pt-doped alloy, its average thickness was $4.61 \mu \mathrm{m}$ ), and at $1100^{\circ} \mathrm{C}$, between 1.43 and $2.55 \mu \mathrm{m}$ (except the Ag-doped alloy, its average thickness was $4.52 \mu \mathrm{m}$ ). Figure 9 shows the thickness of the oxide formed on the intermetallic alloys oxidized to $900^{\circ} \mathrm{C}$; similar aspects were observed at higher temperatures. At all test temperatures, the Pd-doped alloy showed the oxide layer with the lowest thickness (Figure 10(a)). In general, all doped alloys developed an Alrich monolayer oxide (Figures 10(a)-10(c)), as has been reported in other studies [79]. In the case of alloys doped with $\mathrm{Pt}\left(\right.$ at $\left.1000^{\circ} \mathrm{C}\right)$ and with $\mathrm{Ag}\left(\right.$ at $\left.1100^{\circ} \mathrm{C}\right)$, zones with multilayer oxides and thicknesses up to $20 \mu \mathrm{m}$ were observed (Figures 10(d) and 10(g)). In all cases, an Al-depleted zone was observed at the interface alloy oxide (Figures 8 and 10). This is due to the consumption of this element for the formation of protective oxide, $\mathrm{Al}_{2} \mathrm{O}_{3}$ [80]. Similar depletion processes have been reported in studies of corrosion by molten salts [81-85].

Figure 11 shows the surface morphology of the oxides formed at $900^{\circ} \mathrm{C}$. The formation of oxides in the form of needles can be observed only onto nondoped alloy and onto those alloys doped with Ag and Au. This type of morphology is associated with the presence of the metastable phases of alumina [86-88], whose transformation from $\gamma-\mathrm{Al}_{2} \mathrm{O}_{3}$ to $\theta-\mathrm{Al}_{2} \mathrm{O}_{3}$ occurs between 800 and $950^{\circ} \mathrm{C}$ [72]. It is worth mentioning that the alloys that presented this type of morphology had a greater weight gain (Figure 4(a)).

Figure 12 shows the surface morphology of the oxide scale at $1000^{\circ} \mathrm{C}$. It is observed that, at this temperature, there is a greater presence of oxides in the form of needles $\left(\theta-\mathrm{Al}_{2} \mathrm{O}_{3}\right)$ both in the nondoped alloy and in those alloys doped with Ag, Au, and Pt. The alloy doped with Pd showed a lower presence of this phase, possibly due to a decrease in the growth rate of the $\theta-\mathrm{Al}_{2} \mathrm{O}_{3}$ phase. Again, the surface morphology is correlated with the observed weight gain (Figure 4(b)); that is, the greater the presence of the $\theta-\mathrm{Al}_{2} \mathrm{O}_{3}$ phase, the greater the mass gain.

On the other hand, the morphology of the oxides formed at $1100^{\circ} \mathrm{C}$ was completely different (Figure 13). In this case, the oxides formed show wrinkle shaped, which is characteristic of the $\alpha-\mathrm{Al}_{2} \mathrm{O}_{3}$ phase [72]. This morphology is more evident in the nondoped alloy and in those doped with $\mathrm{Ag}$ 


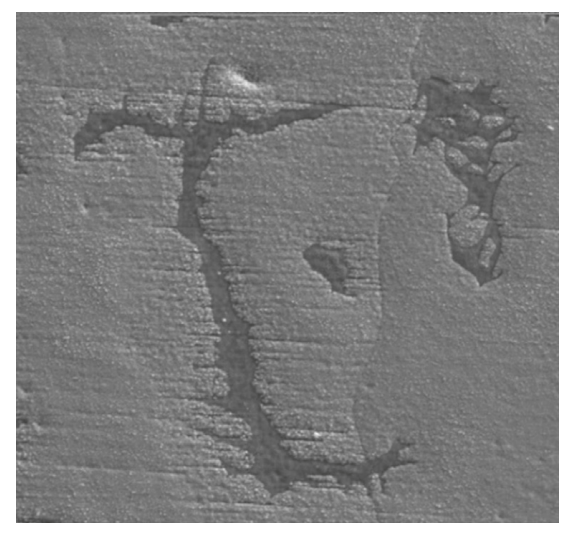

$80 \mu \mathrm{m}$ Mixed

(a)

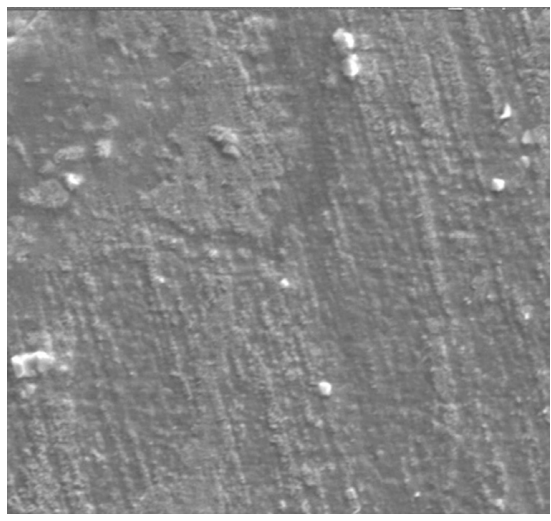

$40 \mu \mathrm{m}$ Mixed

(d)

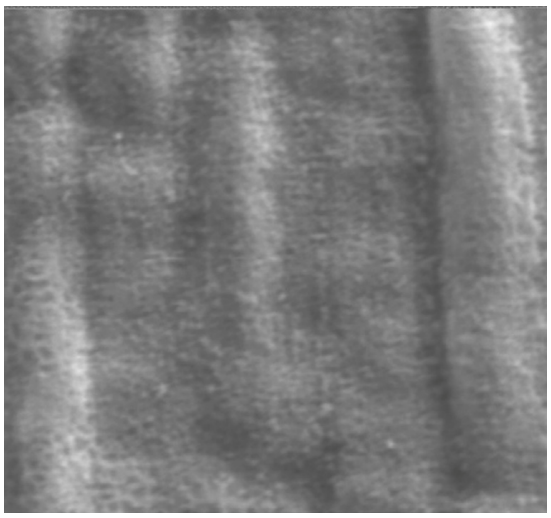

$20 \mu \mathrm{m}$ Mixed

(g)

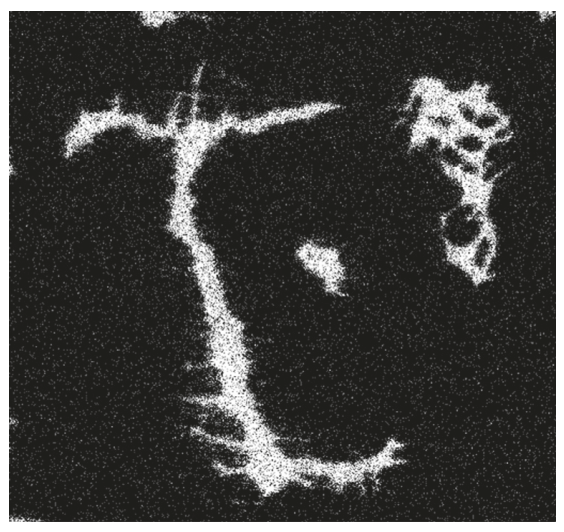

$80 \mu \mathrm{m}$

b)

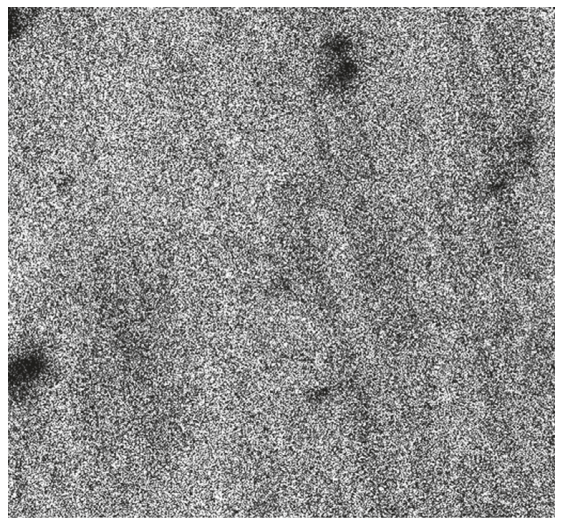

$40 \mu \mathrm{m}$

Aluminum Ka1

(e)

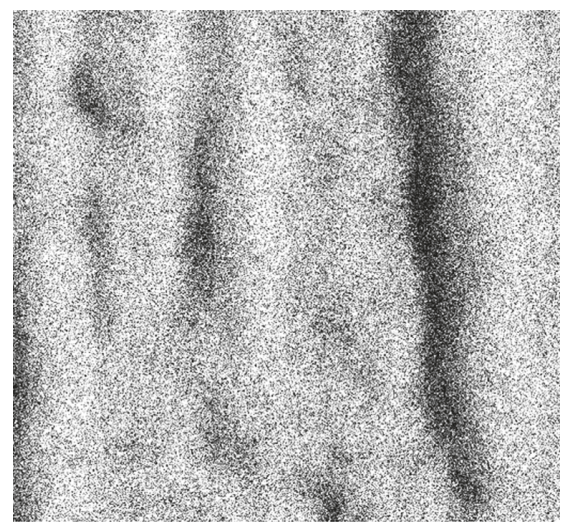

$20 \mu \mathrm{m}$

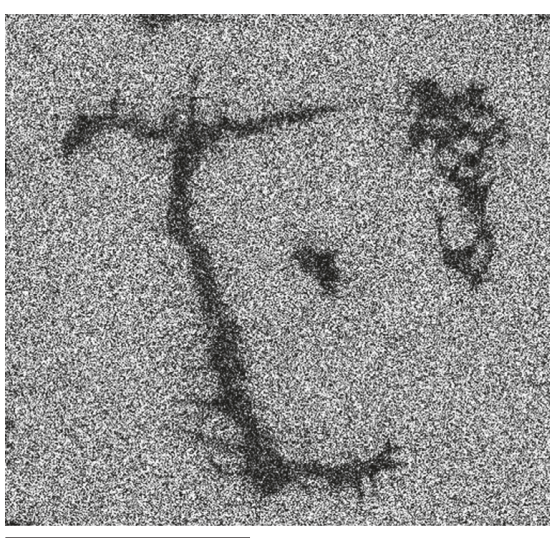

$80 \mu \mathrm{m}$

Nickel Ka1 (c)

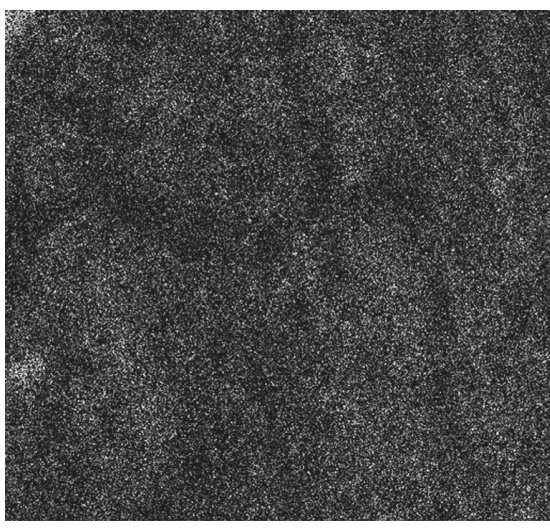

$40 \mu \mathrm{m}$

Nickel Kal

(f)

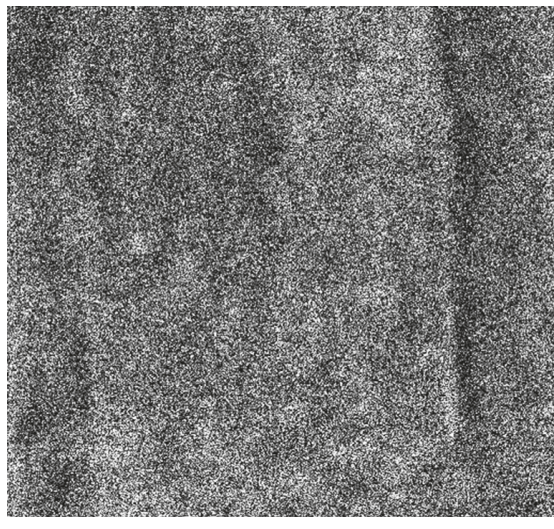

$20 \mu \mathrm{m}$
Nickel Kal

(i)

FIgURE 14: Superficial aspect and mapping elements of the oxide scale formed onto $\mathrm{Ni}_{3} \mathrm{Al}$ at (a) $900^{\circ} \mathrm{C}$, (d) $1000^{\circ} \mathrm{C}$, and $(\mathrm{g}) 1100^{\circ} \mathrm{C}$.

and $\mathrm{Au}$, and in the alloys doped with $\mathrm{Pd}$ and $\mathrm{Pt}$, a more compact and dense morphology was observed. These morphological differences indicate a difference in the growth rates of the oxide layers. In all cases, the weight gain at $1100^{\circ} \mathrm{C}$ was lower than that observed at $1000^{\circ} \mathrm{C}$ (Figure 4). This suggests that oxide layers rich in $\alpha-\mathrm{Al}_{2} \mathrm{O}_{3}$ are more protective than those rich in $\theta-\mathrm{Al}_{2} \mathrm{O}_{3}$.

Figure 14 shows the typical morphology of the $\mathrm{Ni}_{3} \mathrm{Al}$ oxidized in oxygen for 24 hours. In general, a granular scale involving both heterogeneous $\mathrm{Ni}$ and $\mathrm{Al}$ oxides, mainly $\mathrm{Ni}$ 


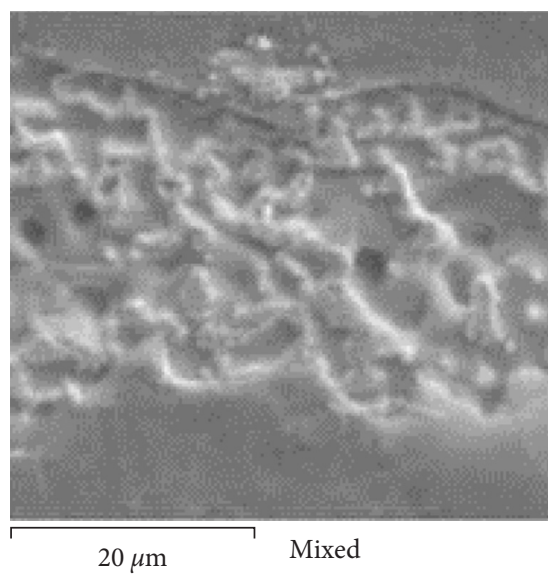

(a)

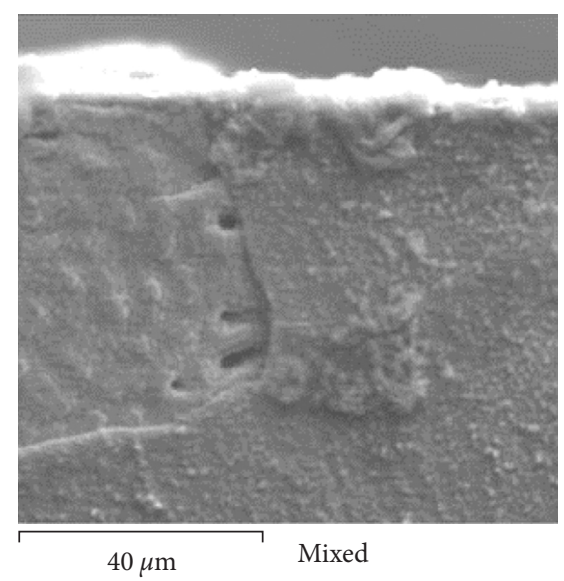

(b)

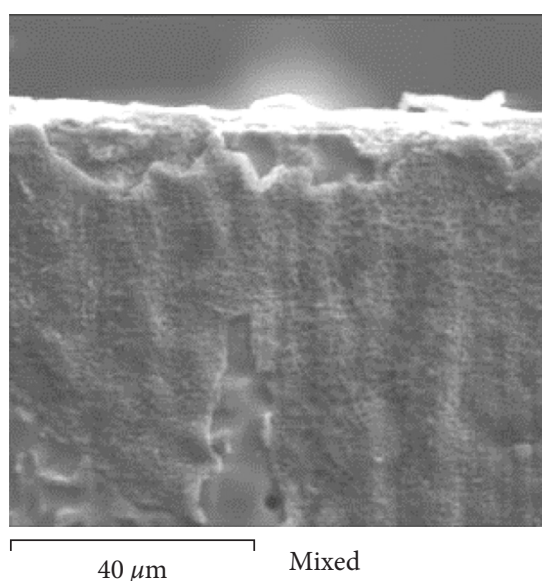

(c)

Figure 15: Cavities formed due to diffusion of $\mathrm{Al}$ during the oxidation process of the $\mathrm{Ni}_{3} \mathrm{Al}$ in oxygen at (a) $900^{\circ} \mathrm{C}$, (b) $1000^{\circ} \mathrm{C}$, and (c) $1100^{\circ} \mathrm{C}$.

oxides, as reported by Cao et al. [77] were observed. At $900^{\circ} \mathrm{C}$, there are well-defined regions rich in $\mathrm{Al}_{2} \mathrm{O}_{3}$ which largely coincide with the interdendritic regions (Figure 14(a)). This suggests that the lateral growth of $\mathrm{NiO}$ could not fully cover the $\mathrm{Al}_{2} \mathrm{O}_{3}$, and the initial stage of oxidation occurred preferentially in the interdendritic phases [11]. At 1000 and $1100^{\circ} \mathrm{C}$, the $\mathrm{Ni}_{3} \mathrm{Al}$ surface was oxidized uniformly in comparison with the oxidized alloy at $900^{\circ} \mathrm{C}$, but the surface mainly contains $\mathrm{Al}_{2} \mathrm{O}_{3}$ (Figures 14(d) and 14(g)). In some regions, the oxide layer has been cracked, probably during cooling, and it was possible to observe the presence of cavities into the scalealloy interface (Figure 15). These sorts of cavities are formed by the consumption of $\mathrm{Al}$ and $\mathrm{Ni}$ in the course of formation of the oxide scale, and they have an impact on the adhesion of the scale [70].

The difference in the oxidation process between the dendritic and the interdendritic phases lies in the thermochemistry of alumina formation between the phases; that is, in the NiAl-rich dendritic phase, the following reaction may occur:

$$
4 \mathrm{NiAl}+3 \mathrm{O}_{2} \leftrightarrows 2 \mathrm{Al}_{2} \mathrm{O}_{3}+4 \mathrm{Ni}\left(\Delta G=-940.52 \mathrm{~kJ} @ 900^{\circ} \mathrm{C}\right)
$$

On the other hand, in the interdendritic phase where the $\mathrm{Ni3 \textrm {Al }}$ phase predominates, the following reaction occurs:

$$
4 \mathrm{Ni}_{3} \mathrm{Al}+3 \mathrm{O}_{2} \leftrightarrows 2 \mathrm{Al}_{2} \mathrm{O}_{3}+12 \mathrm{Ni}\left(\Delta G=-895.40 \mathrm{~kJ} @ 900^{\circ} \mathrm{C}\right)
$$

Thermochemically, the dendritic phase is more favored than the interdendritic phase. Considering also that in the doped alloys there is a considerable decrease in the dendritic phase (Section 3.2), it can be established that there exists a relation between the microstructural change and the thermochemical equilibrium conditions for the formation of an alumina layer. On the other hand, the absence of $\mathrm{NiO}$ in the surface of the doped alloys can also be attributed to the increase in the grain size of the $\mathrm{Al}_{2} \mathrm{O}_{3}$; that is, to say, a decrease in the diffusion of $\mathrm{Ni}$ through the grain boundaries of the $\mathrm{Al}_{2} \mathrm{O}_{3}$ layer, which is related to the kinetics of subparabolic growth.

\section{Conclusions}

The XRD analysis of the alloys showed that the addition of $1 \%$ (atomic percent) of noble metals to the $\mathrm{Ni}_{3} \mathrm{Al}$ intermetallic alloy promotes the preferential growth planes and increases the solidification rate by changing the microstructure of the base alloy. The oxidation behavior of doped alloys may be attributable to the change in the surface composition, taking into account that every growth plane has different compositions and that the preferential substitution site of the noble metals in the structure of $\mathrm{Ni}_{3} \mathrm{Al}$ increases the $\mathrm{Al} / \mathrm{Ni}$ ratio. In general, the addition of noble metals promotes the formation of oxide layers rich in $\mathrm{Al}_{2} \mathrm{O}_{3}$ and is evident that the diffusion of the $\mathrm{Ni}$ cations through $\mathrm{Al}_{2} \mathrm{O}_{3}$ scale is decreased, since the formation of $\mathrm{NiO}$ during the test time was not evident. $\mathrm{Ag}$ and $\mathrm{Au}$ additions increase the value of the parabolic rate constant $k_{p}$, while $\mathrm{Pd}$ and $\mathrm{Pt}$ decrease, the $k_{p}$ values tend to values where the formation of $\theta-\mathrm{Al}_{2} \mathrm{O}_{3}$ and $\alpha-\mathrm{Al}_{2} \mathrm{O}_{3}$ is possible. The noble metal addition increased the activation energy value of the oxidation process compared to the nondoped $\mathrm{Ni}_{3} \mathrm{Al}$, except $\mathrm{Pd}$. The low solubility of $\mathrm{Ag}$ and its low melting point caused microstructural localized failures into Ag-doped alloy.

\section{Conflicts of Interest}

The authors declare that they have no conflicts of interest regarding the publication of this paper.

\section{Acknowledgments}

Financial support from Consejo Nacional de Ciencia y Tecnología (CONACYT, México) (Project no. 159898 and Ph.D. scholarship to J. J. Ramos-Hernandez, Registration no. 202898) is gratefully acknowledged. 


\section{References}

[1] S. C. Deevi and V. K. Sikka, "Nickel and iron aluminides: an overview on properties, processing, and applications," Intermetallics, vol. 4, no. 5, pp. 357-375, 1996.

[2] A. S. Verin, "Certain features of the structure and anisotropy in $\mathrm{Ni}_{3} \mathrm{Al}$ single crystals," Metal Science and Heat Treatment, vol. 36, no. 2, pp. 99-102, 1994.

[3] A. Chiba and S. Hanada, "Relationship between the APD structure and ductility of rapidly solidified $\mathrm{Ni}_{3} \mathrm{Al}$ alloys," Intermetallics, vol. 4, no. 1, pp. 55-59, 1996.

[4] P. Jozwik, E. Jezierska, and Z. Bojar, "TEM investigations of $\mathrm{Ni}_{3} \mathrm{Al}$-based intermetallic polycrystals," Materials Chemistry and Physics, vol. 81, no. 2-3, pp. 448-451, 2003.

[5] O. Hunziker and W. Kurz, "Solidification microstructure maps in Ni-Al alloys," Acta Materialia, vol. 45, no. 12, pp. 4981-4992, 1997.

[6] T. Mawari and T. Hirano, "Effects of unidirectional solidification conditions on the microstructure and tensile properties of $\mathrm{Ni}_{3} \mathrm{Al}$," Intermetallics, vol. 3, no. 1, pp. 23-33, 1995.

[7] A. Inoue, H. Tomioka, and T. Masumoto, "An improvement of ductility and strength of the L12 compounds in Ni-Al-X (X = Cr, Mn, Fe, Co or Si) systems by melt quenching," Journal of Materials Science Letters, vol. 1, no. 9, pp. 377-380, 1982.

[8] R. Goetzinger, M. Barth, D. M. Herlach, O. Hunziker, and W. Kurz, "Disorder trapping in $\mathrm{Ni}_{3}(\mathrm{Al}, \mathrm{Ti})$ by solidification from the undercooled melt," Materials Science and Engineering: A, vol. 226-228, pp. 415-419, 1997.

[9] J. Sun, C. S. Lee, and J. K. L. Lai, "Deformation microstructure of $\mathrm{Ni}_{3} \mathrm{Al}$ intermetallic compound macroalloyed with $\mathrm{Pd}$," Materials Letters, vol. 31, no. 1-2, pp. 1-4, 1997.

[10] B. A. Pint, S. A. Speakman, C. J. Rawn, and Y. Zhang, "Deformation and phase transformations during the cyclic oxidation of $\mathrm{Ni}-\mathrm{Al}$ and Ni-Pt-Al," The Journal of the Minerals, Metals \& Materials Society, vol. 58, no. 1, pp. 47-52, 2006.

[11] D. Lee, M. L. Santella, I. M. Anderson, and G. M. Pharr, "Thermal aging effects on the microstructure and short-term oxidation behavior of a cast $\mathrm{Ni}_{3} \mathrm{Al}$ alloy," Intermetallics, vol. 13, no. 2, pp. 187-196, 2005.

[12] M. Haerig and $\mathrm{S}$. Hofmann, "Mechanisms of $\mathrm{Ni}_{3} \mathrm{Al}$ oxidation between $500^{\circ} \mathrm{C}$ and $700^{\circ} \mathrm{C}$," Applied Surface Science, vol. 125 , no. 1, pp. 99-114, 1998.

[13] U. Bardi, A. Atrei, and G. Rovida, "Initial stages of oxidation of the $\mathrm{Ni}_{3} \mathrm{Al}$ alloy: a study by $\mathrm{X}$-ray photoelectron spectroscopy and low energy He+ scattering," Surface Science, vol. 239, no. 1-2, pp. L511-L516, 1990.

[14] C. Mei, S. Patu, S. Changxu, and S. Jianian, "Effects of B+ and $\mathrm{Cr}+$ ion implantation on the oxidation of $\mathrm{Ni}_{3} \mathrm{Al}$," Journal of Materials Science, vol. 28, no. 20, pp. 5508-5513, 1993.

[15] A. Velon and I. Olefjord, "Oxidation behavior of $\mathrm{Ni}_{3} \mathrm{Al}$ and $\mathrm{Fe}_{3} \mathrm{Al}$ : II. Early stage of oxide growth," Oxidation of Metals, vol. 56, no. 5-6, pp. 425-452, 2001.

[16] T. Norby and P. Kofstad, "Electronic, ionic, and protonic conductivities of a commercial, polycrystalline $\alpha-\mathrm{Al}_{2} \mathrm{O}_{3}$," High Temperatures-High Pressures, vol. 20, pp. 345-360, 1988.

[17] D. B. Lee and M. L. Santella, "High temperature oxidation of $\mathrm{Ni}_{3} \mathrm{Al}$ alloy containing $\mathrm{Cr}, \mathrm{Zr}, \mathrm{Mo}$, and B," Materials Science and Engineering: A, vol. 374, no. 1-2, pp. 217-223, 2004.

[18] S. G. Addepalli, B. Ekstrom, N. P. Magtoto, J. Lin, and J. A. Kelber, "STM atomic-scale characterization of the $\gamma^{\prime}-\mathrm{Al}_{2} \mathrm{O}_{3}$ film on $\mathrm{Ni}_{3} \mathrm{Al}(111)$," Surface Science, vol. 442, no. 3, pp. 385-389, 1999.
[19] A. M. Venezia and C. M. Loxton, "Low pressure oxidation of $\mathrm{Ni}_{3} \mathrm{Al}$ alloys at elevated temperatures as studied by $\mathrm{X}$-ray photoelectron spectroscopy and Auger spectroscopy," Surface Science, vol. 194, no. 1-2, pp. 136-148, 1988.

[20] A. M. Venezia, C. M. Loxton, and J. A. Horton, "Temperature and pressure effects for oxygen adsorption and oxidation of $\mathrm{Ni}_{3} \mathrm{Al}$ alloyed with chromium and zirconium," Surface Science, vol. 225, no. 1-2, pp. 195-205, 1990.

[21] U. Bardi, A. Atrei, and G. Rovida, "Initial stages of oxidation of the $\mathrm{Ni}_{3} \mathrm{Al}$ alloy: structure and composition of the aluminum oxide overlayer studied by XPS, LEIS and LEED," Surface Science, vol. 268, no. 1-3, pp. 87-97, 1992.

[22] P. Pérez, J. L. González-Carrasco, P. Adeva, V. A. C. Haanappel, and M. F. Stroosnijder, "Effect of Cr- and Y-implantation on oxidation behaviour of powder metallurgical $\mathrm{Ni}_{3} \mathrm{Al}$," Materials Science and Technology, vol. 15, no. 3, pp. 345-351, 1999.

[23] M. Garza, N. P. Magtoto, and J. A. Kelber, "Characterization of oxidized $\mathrm{Ni}_{3} \mathrm{Al}(110)$ and interaction of the oxide film with water vapor," Surface Science, vol. 519, no. 3, pp. 259-268, 2002.

[24] V. A. C. Haanappel, P. Pérez, J. L. González-Carrasco, and M. F. Stroosnijder, "The cyclic oxidation behaviour of $\mathrm{PM} \mathrm{Ni}{ }_{3} \mathrm{Al}$ in air at elevated temperatures: the effect of $\mathrm{Cr}-$ and Y-implantation," Intermetallics, vol. 6, no. 5, pp. 347-356, 1998.

[25] T. T. Chang, Y. C. Pan, and T. H. Chuang, "The oxidation behavior of $\mathrm{Ni}_{3} \mathrm{Al}-\mathrm{Zr}$ alloys with various zirconium contents," Journal of Alloys and Compounds, vol. 243, no. 1-2, pp. 126-132, 1996.

[26] D. B. Lee and D. J. Kim, "The oxidation of $\mathrm{Ni}_{3} \mathrm{Al}$ containing decomposed SiC-particles," Intermetallics, vol. 9, no. 1, pp. 51-56, 2001.

[27] W. W. Lee, D. B. Lee, M. H. Kim, and S. C. Ur, "High temperature oxidation of an oxide-dispersion strengthened NiAl," Intermetallics, vol. 7, no. 12, pp. 1361-1366, 1999.

[28] A. Velon and D. Q. Yi, "Influence of Cr on the Oxidation of $\mathrm{Fe}_{3} \mathrm{Al}$ and $\mathrm{Ni}_{3} \mathrm{Al}$ at $500^{\circ} \mathrm{C}$," Oxidation of Metals, vol. 57, pp. 13-31, 2002.

[29] V. Deodeshmukh, N. Mu, B. Li, and B. Gleeson, "Hot corrosion and oxidation behavior of a novel $\mathrm{Pt}+\mathrm{Hf}$-modified $\gamma^{\prime}-\mathrm{Ni}_{3} \mathrm{Al}+\gamma$-Ni-based coating," Surface and Coatings Technology, vol. 201, no. 1, pp. 3836-3840, 2006.

[30] F. Qin, J. W. Anderegg, C. J. Jenks, B. Gleeson, D. J. Sordelet, and P. A. Thiel, "The effect of Pt on $\mathrm{Ni}_{3} \mathrm{Al}$ surface oxidation at low-pressures," Surface Science, vol. 601, no. 1, pp. 146-154, 2007.

[31] S. J. Hong, G. H. Hwang, W. K. Han, and S. G. Kang, "Cyclic oxidation of Pt/Pd-modified aluminide coating on a nickelbased superalloy at $1150^{\circ} \mathrm{C}$," Intermetallics, vol. 17 , no. 6 , pp. 381-386, 2009.

[32] B. Gleeson, N. Mu, and S. Hayashi, "Compositional factors affecting the establishment and maintenance of $\mathrm{Al}_{2} \mathrm{O}_{3}$ scales on Ni-Al-Pt systems," Journal of Materials Science, vol. 44, no. 7, pp. 1704-1710, 2009.

[33] A. V. Ruban and H. L. Skriver, "Calculated site substitution in ternary $\gamma^{\prime}-\mathrm{Ni}_{3} \mathrm{Al}$ : temperature and composition effects," Physical Review B, vol. 55, no. 2, pp. 856-874, 1997.

[34] C. Wolverton and D. De Fontaine, "Site substitution of ternary additions to $\mathrm{Ni}_{3} \mathrm{Al}\left(\gamma^{\prime}\right)$ from electronic-structure calculations," Physical Review B, vol. 49, no. 17, pp. 1235112354, 1994.

[35] C. Y. Geng, C. Y. Wang, and T. Yu, "Site preference and alloying effect of platinum group metals in $\gamma^{\prime}-\mathrm{Ni}_{3} \mathrm{Al}$," Acta Materialia, vol. 52, no. 18, pp. 5427-5433, 2004. 
[36] C. Jiang and B. Gleeson, "Site preference of transition metal elements in $\mathrm{Ni}_{3} \mathrm{Al}$," Scripta Materialia, vol. 55, no. 5, pp. 433-436, 2006.

[37] C. Jiang, D. J. Sordelet, and B. Gleeson, "Site preference of ternary alloying elements in $\mathrm{Ni}_{3} \mathrm{Al}$ : a first-principles study," Acta Materialia, vol. 54, no. 4, pp. 1147-1154, 2006.

[38] B. Bhattacharya and R. K. Ray, "Deformation behavior of a $\mathrm{Ni}_{3} \mathrm{Al}(\mathrm{B}, \mathrm{Zr})$ alloy during cold rolling: part I. Changes in order and structure," Metallurgical and Materials Transactions $A$, vol. 31, no. 12, pp. 3001-3010, 2000.

[39] Y. Xu, S. Kameoka, K. Kishida, M. Demura, A. P. Tsai, and T. Hirano, "Catalytic properties of $\mathrm{Ni}_{3} \mathrm{Al}$ intermetallics for methanol decomposition," Materials Transactions, vol. 45, no. 11, pp. 3177-3179, 2004.

[40] L. Lu, M. O. Lai, and S. Zhang, "Evolution and characterization of a $\mathrm{Ni}_{3} \mathrm{Al}$ intermetallic compound during mechanical alloying," Materials \& Design, vol. 15, no. 2, pp. 79-86, 1994.

[41] T. Hirano, "Improvement of room temperature ductility of stoichiometric $\mathrm{Ni}_{3} \mathrm{Al}$ by unidirectional solidification," Acta metallurgica et materialia, vol. 38, no. 12, pp. 2667-2671, 1990.

[42] B. D. Cullity and S. R. Stock, Elements of X-ray Diffraction, , pp. 125-170, Prentice Hall, Pearson New Iinternational Edition, Upper Saddle River, NJ, USA, 2014.

[43] R. Seymour, A. Hemeryck, K. I. Nomura et al., "Nanoindentation of $\mathrm{NiAl}$ and $\mathrm{Ni}_{3} \mathrm{Al}$ crystals on (100), (110), and (111) surfaces: a molecular dynamics study," Applied Physics Letters, vol. 104, no. 14, p. 141904, 2014.

[44] G. F. Cotterill, H. Niehus, and D. J. O'Connor, "An STM study of the initial stages of oxidation of $\mathrm{Ni}_{3} \mathrm{Al}(110)$," Surface Review and Letters, vol. 3, no. 3, pp. 1355-1363, 1996.

[45] Y. G. Shen, D. J. O’Connor, and R. J. MacDonald, "Studies of surface composition, structure and oxygen adsorption of $\mathrm{Ni}_{3} \mathrm{Al}$ (110) by $\mathrm{Li}+$ and $\mathrm{He}+$ ion scattering," Surface and Interface Analysis, vol. 18, no. 10, pp. 729-739, 1992.

[46] A. Rosenhahn, J. Schneider, C. Becker, and K. Wandelt, "Oxidation of $\mathrm{Ni}_{3} \mathrm{Al}(111)$ at 600,800 , and $1050 \mathrm{~K}$ investigated by scanning tunneling microscopy," Journal of Vacuum Science \& Technology A: Vacuum, Surfaces, and Films, vol. 18, no. 4, pp. 1923-1927, 2000.

[47] S. Degen, A. Krupski, M. Kralj et al., "Determination of the coincidence lattice of an ultra thin $\mathrm{Al}_{2} \mathrm{O}_{3}$ film on $\mathrm{Ni}_{3} \mathrm{Al}$ (111)," Surface science, vol. 576, no. 1-3, pp. L57-L64, 2005.

[48] A. Rosenhahn, J. Schneider, C. Becker, and K. Wandelt, "The formation of $\mathrm{Al}_{2} \mathrm{O}_{3}$-layers on $\mathrm{Ni}_{3} \mathrm{Al}$ (111)," Applied Surface Science, vol. 142, no. 1-4, pp. 169-173, 1999.

[49] S. P. Chen, A. F. Voter, and D. J. Srolovitz, "Oscillatory surface relaxations in $\mathrm{Ni}, \mathrm{Al}$, and their ordered alloys," Physical Review Letters, vol. 57, no. 11, pp. 1308-1311, 1986.

[50] W. J. Chia and Y. W Chung, "Surface spectroscopy and temperature-programmed desorption studies of the interaction of water vapor with $\mathrm{Ni}_{3}(\mathrm{Al}, \mathrm{Ti})$ (100) and (111) surfaces as a function of temperature," Intermetallics, vol. 3, no. 6, pp. 505-509, 1995.

[51] O. Hunziker and W. Kurz, "Directional solidification and phase equilibria in the Ni-Al system," Metallurgical and Materials Transactions A, vol. 30, no. 12, pp. 3167-3175, 1999.

[52] G. Rosas, R. Esparza, A. Bedolla, O. Flores, and R. Perez, "Effect of Li alloying on the microstructure and mechanical properties of $\mathrm{Ni}_{3} \mathrm{Al}$," Advances in Technology of Materials and Materials Processing Journal, vol. 9, pp. 99-102, 2007.

[53] M. H. Jacobs, TALAT Lecture 1203: Phase Diagrams, European Aluminium Association, Bruxelles, Belgium, 2010.
[54] E. J. Lavernia and T. S. Srivatsan, "The rapid solidification processing of materials: science, principles, technology, advances, and applications," Journal of Materials Science, vol. 45, no. 2, pp. 287-325, 2010.

[55] Z. Jingchen and Y. Ping, The Effect of Cooling Rate of Solidification on Microstructure and Alloy Element Segregation of as Cast Alloy 718, pp. 133-140, Central Iron and Steel Research Institute, Beijing, China, 2015.

[56] J. Xu, U. Herr, T. Klassen, and R. S. Averback, "Formation of supersaturated solid solutions in the immiscible Ni-Ag system by mechanical alloying," Journal of Applied Physics, vol. 79, no. 8, pp. 3935-3945, 1996.

[57] J. Zhou and J. T. Guo, "Effect of Ag alloying on the microstructure of NiAl," Materials Letters, vol. 56, no. 3, pp. 178$182,2002$.

[58] J. Zhou and J. T. Guo, "Effect of Ag alloying on microstructure, mechanical and electrical properties of NiAl intermetallic compound," Materials Science and Engineering: A, vol. 339, no. 1-2, pp. 166-174, 2003.

[59] L. Sheng, W. Zhang, J. Guo, F. Yang, Y. Liang, and H. Ye, "Effect of $\mathrm{Au}$ addition on the microstructure and mechanical properties of NiAl intermetallic compound," Intermetallics, vol. 18, no. 4, pp. 740-744, 2010.

[60] C. Meng, J. Guo, and Z. Hu, "Mechanism of macroalloyinginduced ductility in $\mathrm{Ni}_{3} \mathrm{Al}$," Journal of Materials Science \& Technology, vol. 10, pp. 279-284, 1994.

[61] M. J. Li, X. F. Sun, H. R. Guan, X. X. Jiang, and Z. Q. Hu, "The degradation of $(\mathrm{Ni}, \mathrm{Pd}) \mathrm{Al}$ coatings on superalloy IN738 during isothermal oxidation," Surface and Coatings Technology, vol. 185, no. 2-3, pp. 172-177, 2004.

[62] M. J. Li, X. F. Sun, H. R. Guan, X. X. Jiang, and Z. Q. Hu, "Cyclic oxidation behavior of palladium-modified aluminide coating," Surface and Coatings Technology, vol. 167, no. 1, pp. 106-111, 2003.

[63] D. Oquab and D. Monceau, "In-situ SEM study of cavity growth during high temperature oxidation of $\beta$-(Ni,Pd)Al," Scripta Materialia, vol. 44, no. 12, pp. 2741-2746, 2001.

[64] Y. Zhang, J. A. Haynes, W. Y. Lee et al., "Effects of Pt incorporation on the isothermal oxidation behavior of chemical vapor deposition aluminide coatings," Metallurgical and Materials Transactions A, vol. 32, no. 7, pp. 1727-1741, 2001.

[65] P. Peréz, M. Eddahbi, J. L. González-Carrasco, and P. Adeva, "Effect of the processing route on the oxidation behaviour of a $\mathrm{Ni}_{3} \mathrm{Al}$ powder metallurgy alloy," Intermetallics, vol. 7, no. 6 , pp. 679-687, 1999.

[66] J. J. Ramos-Hernandez, J. Porcayo-Calderon, V. M. SalinasBravo, C. D. Arrieta-Gonzalez, J. G. Gonzalez-Rodriguez, and L. Martinez-Gomez, "Phase stability diagrams for high temperature corrosion processes," Mathematical Problems in Engineering, vol. 2013, pp. 1-7, 2013.

[67] A. Atkinson, R. I. Taylor, and A. E. Hughes, "A quantitative demonstration of the grain boundary diffusion mechanism for the oxidation of metals," Philosophical Magazine A, vol. 45, no. 5, pp. 823-833, 1982.

[68] D. Naumenko, B. Gleeson, E. Wessel, L. Singheiser, and W. J. Quadakkers, "Correlation between the microstructure, growth mechanism, and growth kinetics of alumina scales on a FeCrAlY alloy," Metallurgical and Materials Transactions A, vol. 38, no. 12, pp. 2974-2983, 2007.

[69] W. J. Quadakkers, D. Naumenko, E. Wessel, V. Kochubey, and L. Singheiser, "Growth rates of alumina scales on FeCr-Al alloys," Oxidation of Metals, vol. 61, no. 1-2, pp. 17-37, 2004. 
[70] Y. Cadoret, D. Monceau, M. Bacos, P. Josso, V. Maurice, and P. Marcus, "Effect of platinum on the growth rate of the oxide scale formed on cast nickel aluminide intermetallic alloys," Oxidation of Metals, vol. 64, no. 3-4, pp. 185-205, 2005.

[71] S. Hayashi and B. Gleeson, "Early-stage oxidation behavior of Pt-modified $\gamma^{\prime}-\mathrm{Ni}_{3} \mathrm{Al}$-based alloys with and without $\mathrm{Hf}$ addition," Oxidation of Metals, vol. 71, no. 1-2, pp. 5-19, 2009.

[72] M. W. Brumm and H. J Grabke, "The oxidation behaviour of NiAl-I. Phase transformations in the alumina scale during oxidation of NiAl and NiAl-Cr alloys," Corrosion Science, vol. 33, no. 11, pp. 1677-1690, 1992.

[73] S. C. Choi, H. J. Cho, Y. J. Kim, and D. B. Lee, "Hightemperature oxidation behavior of pure $\mathrm{Ni}_{3} \mathrm{Al}$," Oxidation of Metals, vol. 46, no. 1-2, pp. 51-72, 1996.

[74] J. D. Kuenzly and D. L. Douglass, "The oxidation mechanism of $\mathrm{Ni}_{3} \mathrm{Al}$ containing Yttrium," Oxidation of Metals, vol. 8, no. 3, pp. 139-178, 1974.

[75] S. Ochiai, T. Suzuki, Y. Kojima, M. Kobayashi, and Y. Torisaka, "Effect of yttrium addition on the hightemperature oxidation resistance of $\mathrm{Ni}_{3} \mathrm{Al}$ alloy," Journal of the Japan Institute of Metals and Materials, vol. 53, no. 6, pp. 585-592, 1989.

[76] N. Birks, G. H. Meier, and F. S. Pettit, "High-temperature corrosion resistance," Journal of the Minerals, Metals of Materials Society, vol. 39, no. 12, pp. 28-31, 1987.

[77] G. Cao, L. Geng, Z. Zheng, and M. Naka, “The oxidation of nanocrystalline $\mathrm{Ni}_{3} \mathrm{Al}$ fabricated by mechanical alloying and spark plasma sintering," Intermetallics, vol. 15, no. 12, pp. 1672-1677, 2007.

[78] N. Mu, T. Izumi, L. Zhang, and B. Gleeson, "The development and performance of novel $\mathrm{Pt}+\mathrm{Hf}$-modified $\gamma^{\prime}-\mathrm{Ni}_{3} \mathrm{Al}$ $+\gamma$-Ni bond coatings for advanced thermal barrier coatings systems," in Superalloys 2008, R. C. Reed, K. A. Green, P. Caron et al, Eds., TMS (The Minerals, Metals \& Materials Society), 2008.

[79] C. Jiang and B. Gleeson, "Surface segregation of Pt in $\gamma^{\prime}-\mathrm{Ni}_{3} \mathrm{Al}$ : a first-principles study," Acta Materialia, vol. 55, no. 5, pp. 1641-1647, 2007.

[80] Y. Niu, X. J. Zhang, Y. Wu, and F. Gesmundo, "The thirdelement effect in the oxidation of $\mathrm{Ni}-\mathrm{xCr}-7 \mathrm{Al}(\mathrm{x}=0,5,10$, 15at.\%) alloys in $1 \mathrm{~atm} \mathrm{O}_{2}$ at $900-1000^{\circ} \mathrm{C}$," Corrosion Science, vol. 48, no. 12, pp. 4020-4036, 2006.

[81] J. Porcayo-Calderon, O. Sotelo-Mazon, V. M. Salinas-Bravo, C. D. Arrieta-Gonzalez, J. J. Ramos-Hernandez, and C. Cuevas-Arteaga, "Electrochemical performance of $\mathrm{Ni}_{2} \mathrm{OCr}$ coatings applied by combustion powder spray in $\mathrm{ZnCl}_{2}-\mathrm{KCl}$ molten salts," International Journal of Electrochemical Science, vol. 7, pp. 1134-1148, 2012.

[82] A. Luna-Ramirez, J. Porcayo-Calderon, G. Salinas-Solano, C. D. Arrieta-Gonzalez, V. M. Salinas-Bravo, and L. Martinez, "Electrochemical performance of $\mathrm{Fe}-\mathrm{Al}$ intermetallic alloys with addition of $\mathrm{Li}, \mathrm{Ni}$ and $\mathrm{Ce}$ in $\mathrm{NaVO}_{3}$ at $700^{\circ} \mathrm{C}$," International Journal of Electrochemical Science, vol. 8, pp. 4641-4653, 2013.

[83] J. Porcayo-Calderon, O. Sotelo-Mazon, M. Casales-Diaz, J. A. Ascencio-Gutierrez, V. M. Salinas-Bravo, and L. Martinez-Gomez, "Electrochemical study of $\mathrm{Ni}_{2} \mathrm{OCr}$ coatings applied by $\mathrm{HVOF}$ process in $\mathrm{ZnCl}_{2}-\mathrm{KCl}$ at high temperatures," Journal of Analytical Methods in Chemistry, vol. 2014, pp. 1-11, 2014

[84] G. Salinas-Solano, J. Porcayo-Calderon, J. G. GonzalezRodriguez, V. M. Salinas-Bravo, J. A. Ascencio-Gutierrez, and L. Martinez-Gomez, "High temperature corrosion of inconel
600 in NaCl-KCl molten salts," Advances in Materials Science and Engineering, vol. 2014, pp. 1-9, 2014.

[85] O. Sotelo-Mazon, J. Porcayo-Calderon, C. Cuevas-Arteaga et al., "Corrosion performance of Ni-based alloys in sodium metavanadate," International Journal of Electrochemical Science, vol. 11, pp. 1868-1882, 2016.

[86] J. Doychak, J. L. Smialek, and C. A. Barrett, "The oxidation of Ni-rich Ni-Al intermetallics," in Oxidation of High Tempereture Intermetallics, T. Grobstein and J. Doychak, Eds., p. 41, Minerals, Metals \& Material Society, 1988.

[87] K. Zhao, Y. B. Zhou, Y. H. Ma, L. H. Lou, and Z. Q. Hu, "Effect of microstructure on the oxidation behavior of two nickelbased superalloys," Corrosion, vol. 61, no. 10, pp. 961-967, 2005.

[88] G. Liu, M. Li, M. Zhu, and Y. Zhou, "Transient of alumina oxide scale on $\beta$-NiAl coated on M38G alloy at $950^{\circ} \mathrm{C}$," Intermetallics, vol. 15, no. 10, pp. 1285-1290, 2007. 


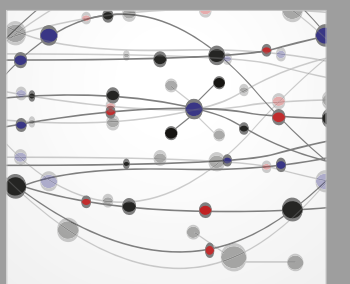

The Scientific World Journal
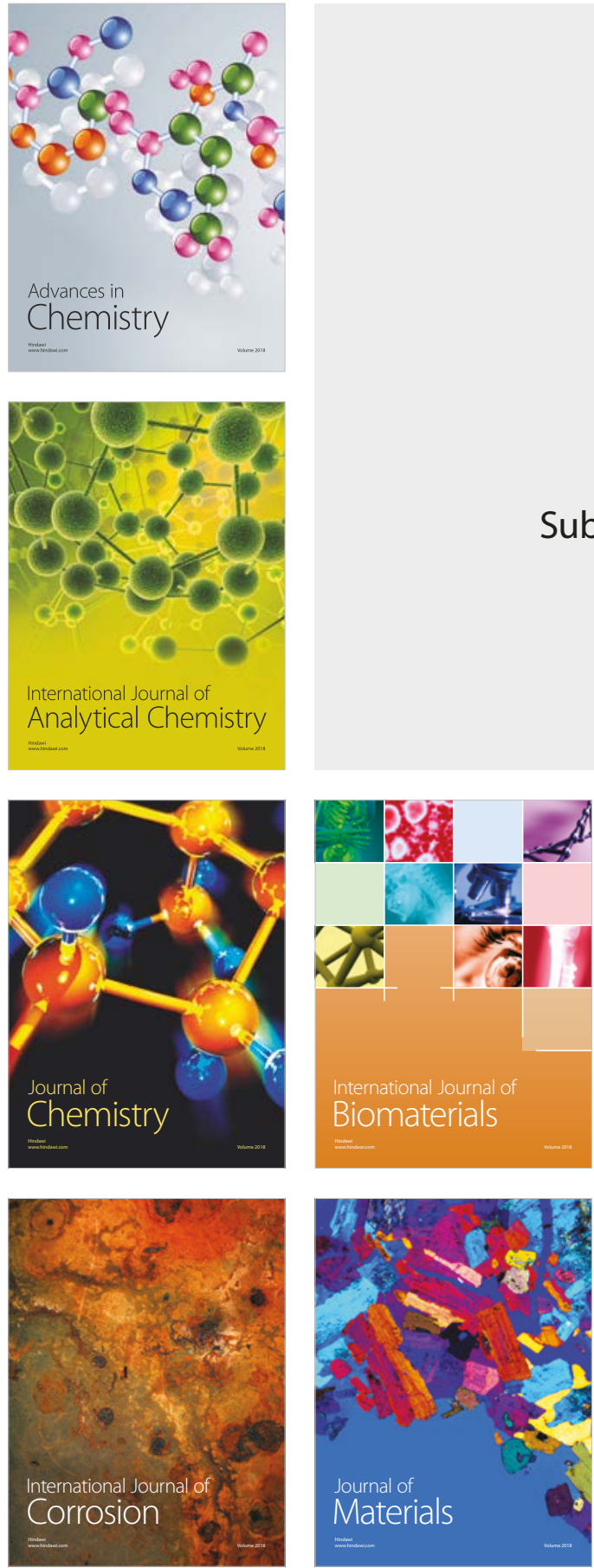

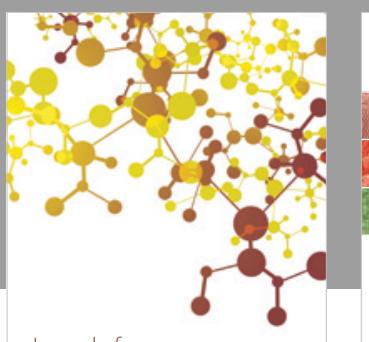

Journal of

Applied Chemistry
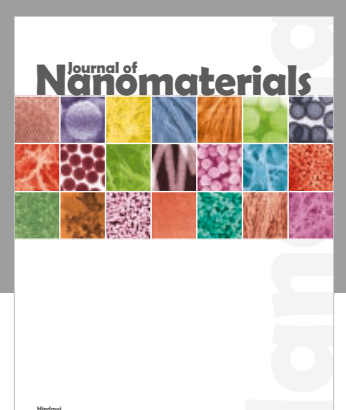

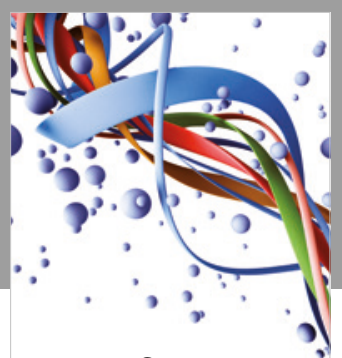

Scientifica

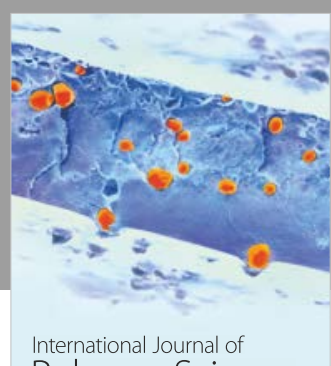

Polymer Science

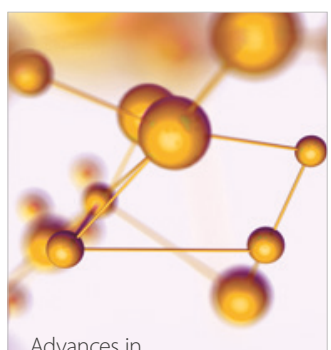

Physical Chemistry
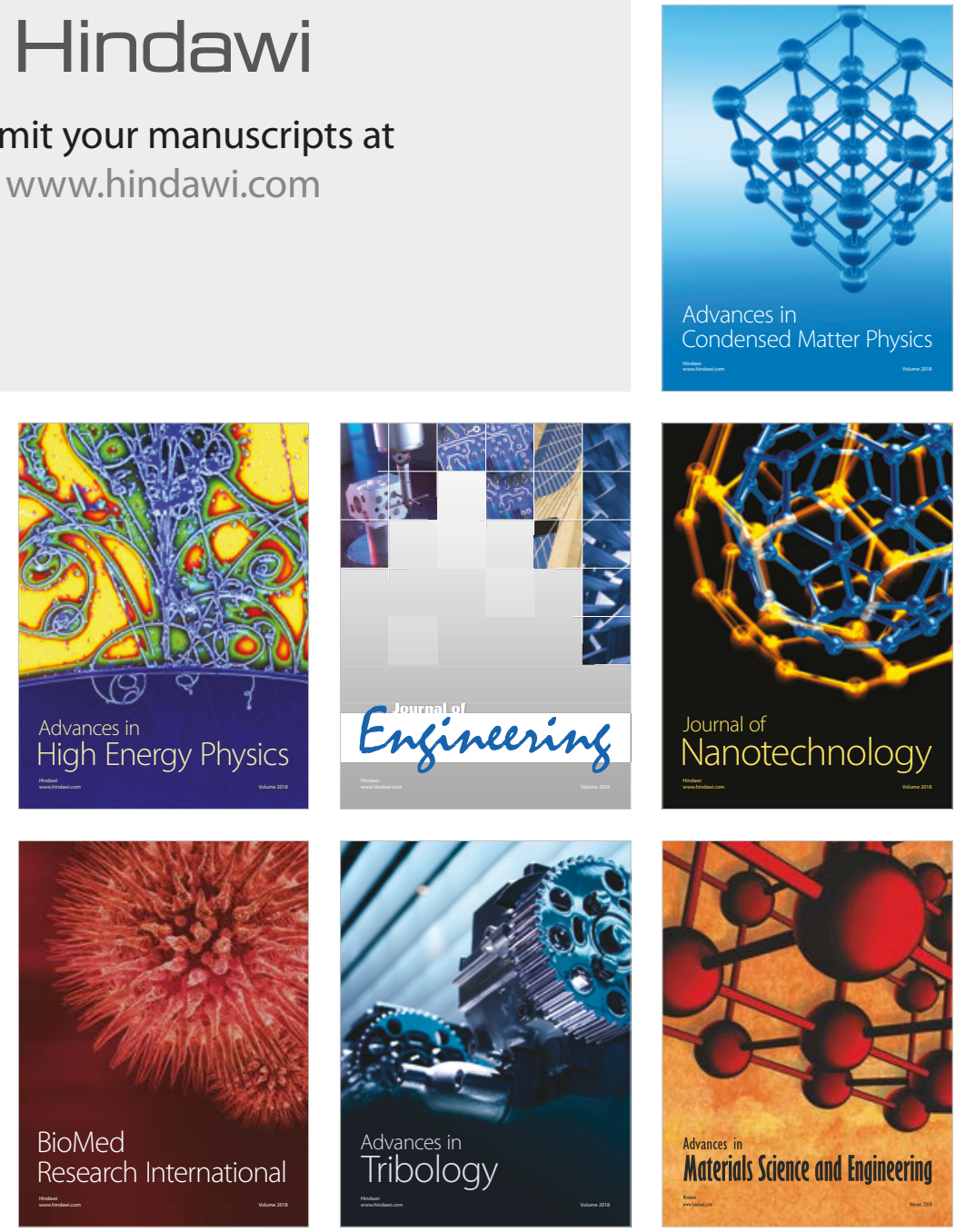